ARCHIWA - KanCELARIE - ZBIORY

NR 3(5)/2012

Aleksander SmOliński

Uniwersytet Mikotaja Kopernika w Toruniu

\title{
Próba OCENY WARTó́ci POZNAWCZEJ AKT pozostaŁych po Oddziale II SzTabu GŁównego WOJSKa POLSKIEgO W KONTEKŚCIE MOŻLIWOŚCI OPISU SYTUACJI WOJSKOWEJ, EKONOMICZNEJ I SPOŁECZNEJ ZSRS W LATACH 1921-1939
}

Słow a kluczowe: Oddział II Sztabu Głównego Wojska Polskiego, polski wywiad wojskowy, wywiad polski w Związku Sowieckim, polsko-sowieckie stosunki polityczne, polsko-sowieckie stosunki wojskowe, zasób Centralnego Archiwum Wojskowego w Warszawie, zasób Archiwum Akt Nowych w Warszawie, zasób Rosyjskiego Państwowego Archiwum Wojskowego w Moskwie, zasób Centrum Przechowywania Historyczno-Dokumentalnych Kolekcji w Moskwie, zespół akt Oddziału II Sztabu Głównego (Generalnego) Wojska Polskiego, wartość informacyjna akt wywiadu wojskowego, Robotniczo-Chłopska Armia Czerwona, sowiecki potencjał militarny, sowieckie przygotowania wojenne, sowiecki wywiad wojskowy

Key w ords: Division II of the General Staff of the Polish Armed Forces, Polish military intelligence, Polish intelligence in the Soviet Union, the Polish-Soviet political relations, the Polish-Soviet military relations, the Central Military Archives in Warsaw, the New Records Archives in Warsaw, the Russian State Military Archive in Moscow, Centre for the Preservation of Historical Documentary Collections in Moscow, archives of Division II of the General Staff of the Polish Army, information value of the military intelligence records, Workers-Peasants Red Army, the Soviet military power, the Soviet war preparations, the Soviet military intelligence 
Abstract

Autor podjął się analizy wielkości oraz zawartości i wartości poznawczej spuścizny aktowej pozostałej po Oddziale II Sztabu Głównego Wojska Polskiego, dotyczącej zakresu i efektów jego działalności wywiadowczej z lat 1921-1939 wobec Rosji Sowieckiej. Jest ona obecnie przechowywana przez kilka instytucji. Analiza zostały objęte zasoby Centralnego Archiwum Wojskowego w Warszawie, Archiwum Akt Nowych w Warszawie, Rosyjskiego Państwowego Archiwum Wojskowego w Moskwie, w którego skład wchodzą materiały niegdysiejszego Centrum Przechowywania Historyczno-Dokumentalnych Kolekcji. Z artykułu wynika, że rola tych materiałów jest pierwszorzędna w badaniach nad sowieckim zagrożeniem dla Rzeczpospolitej Polskiej w okresie międzywojennym, dla oceny sowieckiego potencjału militarnego z tego okresu oraz innych zjawisk o charakterze ekonomicznym, społecznym i politycznym, które mogły mieć wpływ na przebieg przewidywanego konfliktu zbrojnego.

Traktat ryski, zawarty dnia 18 marca 1921 r. pomiędzy Rzeczpospolitą Polską a Rosyjską Socjalistyczną Federacyjną Republiką Rad i Ukraińską Socjalistyczną Republiką Rad z drugiej strony, w sposób formalny kończył wojnę polsko-sowiecką, czyli jedno z najważniejszych wydarzeń w historii Polski XX wieku. W rzeczywistości jednak, pomimo zawartych w nim postanowień pokojowych, skończyły się wówczas jedynie otwarte działania wojenne. Jednakże część politycznych przyczyn tego konfliktu nadal pozostała nierozstrzygnięta ${ }^{1}$.

W przypadku Polski była to bowiem wojna, która toczyła się nie tylko o taki czy też inny kształt terytorialny odrodzonego po 123 latach niewoli państwa, ale przede wszystkim o samo istnienie niepodległej Rzeczypospolitej. W przypadku drugiej strony tego konfliktu była to natomiast klasyczna „wojna klasowa”2, która w razie bolszewickiego zwycięstwa być może już na

1 Tekst tego traktatu w jego wersji polskojęzycznej, czyli w jednej z dwóch równoważnych i obowiązujących jako oficjalna wykładnia postanowień traktatowych, vide: Dziennik Ustaw Rzeczypospolitej Polskiej Nr 49 z 1921 r. pozycja 300. Jego treść podają także: Dokumenty do dziejów polskiej polityki zagranicznej 1918-1939, t. 1: 1918-1932, pod red. T. Jędruszczaka i M. Nowak-Kiełbikowej, Warszawa 1989 oraz Powstanie II Rzeczypospolitej. Wybór dokumentów 1866-1925, pod red. H. Janowskiej, T. Jędruszczaka, Warszawa 1984.

2 O specyficznych cechach konfliktów tego typu vide choćby: W. I. Lenin, Dzieta wybrane w dwóch tomach, t. 2, Warszawa 1951; М. В. Фрунзе. Избранные произведения. Коллективная работа под наблюдением Н. С. Филиппова, В. Ф. Морозова, Москва 1951; М. В. Фрунзе. Избранные произведения. Составитель Е. П. Моз- 
zawsze, a przynajmniej na bardzo długi czas $^{3}$, oddaliłaby realizację polskich marzeń o niepodległości.

W przeciwieństwie do Polski, rządzącym Rosją bolszewikom niezwykle trudno było pogodzić się z postanowieniami traktatowymi, gdyż na dłuższy czas oddalały one plany realizacji europejskiej rewolucji komunistycznej, której pierwszym etapem, siłą obiektywnie istniejących okoliczności, musiałyby być podbój i komunizacja Rzeczpospolitej Polskiej. Do tego niejako chwilowego „rozejmu” zmuszały ich jednak wewnętrzne problemy polityczne i społeczne. Do głównych z nich należały liczne, niekiedy trwające od lat, i w znacznej części przypadków niezwykle krwawe, powstania chłopskie na

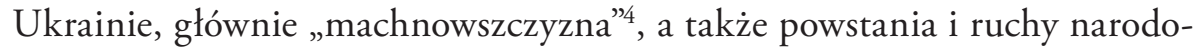

жухин, Москва 1965; M. N. Tuchaczewski, Pisma wybrane, t. 1, wybór i oprac. G. I. Ośkin, P. P. Czernuszkow, Warszawa 1966, a także: R. Pipes, Rosja bolszewików, Warszawa 2005.

3 Pewnym potwierdzeniem tej tezy mogą być długie i niezwykle skomplikowane dzieje walk i starań o niepodległość narodową i państwową, jakie pomiędzy 1917 a 1991 r. (a właściwie 2004 r.) stały się udziałem narodu ukraińskiego - vide choćby: С. Ярославин, Визвольна боротьба на Західньо-Українських Землях у 1918-1923, Филаделфія 1956; Л. Шанковський, Українська армія в боротьбі за державність, Мюнхен 1958; M. Łesiów, Ukraina wczoraj i dziś, Lublin 1995; С. Галамай, Боротьба за визволення України 1929-1989, Торонто-Нью Йорк 1991; I. Т. Муковський, О. С. Лисеико, Звитяга і жертовність. Українці на фронтах другої світової війни, Київ 1997; В. Верига, Визвольні змагання в Україні 1914-1923 рр., Львів 1998; M. Krotofil, Ukrainsska Armia Halicka 1918-1920. Organizacja, uzbrojenie, wyposażenie i wartość bojowa sit zbrojnych Zachodnio-Ukraińskiej Republiki Ludowej, Toruń 2002; J. Legieć, Armia Ukraińskiej Republiki Ludowej w wojnie polsko-ukraińsko-bolszewickiej w 1920 roku, Toruń 2002; Д. Дорошенко, Історія України 1917-1923 рр., Київ 2002; І. Мазепа, Україна в огні й бурі революйії 1917-1921, Київ 2003.

${ }^{4}$ Szerzej vide choćby: Warszawa, Biblioteka Narodowa (dalej cyt.: BN). Archiwum im. Tarasa Szewczenki. Partyzancki Powstańczy Sztab Ukraiński. Mf. Nr 68863. Список повстанческіх відділів на Украіні по стану на 1 VI 1921 р.; tamże, Mf. Nr 68864. Короткий огляд стратегичноі сітуаціі перед східним кордоном Річі Посполитоі Польськоі на 14 VII 1921 р.; tamże, Короткий огляд війсковоі сітуаціі на терені Украіни на 14 VIII 1921 р.; Крестьянская революиия в России 1902-1922. Документы и материалы. Под редакцей В. Данилова, Т. Шанина, Том: Нестор Махно. Крестьянское движение на Украине 1918-1921. Документы и материяль. Ответственные редакторы В. Данилов, В. Кондрашин, Н. Тархова, Л. Яковлева, Москва 2006; А. В. Белаш, В. Ф. Белаш, Дороги Нестора Махно. Историческое повестование, Киев 1993; П. Аршипов, История Махновского движения (1918-1921), Берлин 1923 (II wydanie, Запорожье 1995); В. Телицин, Иестор Махно, Москва-Смоленск 1998. 
we na obszarach rdzennie rosyjskich („antonowszczyzna”) ${ }^{5}$ oraz na Syberii ${ }^{6}$, na Północnym Kaukazie i w Środkowej Azji („basmacze”) ${ }^{7}$, bunty i powstania robotnicze, jak również walka o władzę, jaka toczyła się wewnątrz partii bolszewickiej. Należy także pamiętać, że konieczność tłumienia wspomnianych tutaj powstań chłopskich oraz wszelkich ruchów narodowych i społecznych angażowały spore siły Robotniczo-Chłopskiej Armii Czerwonej, których nie można byłoby wtenczas użyć do ewentualnego konfliktu zewnętrznego. Warto też dodać, iż największa jej część, niezbędna do walki z wewnętrzną „kontrrewolucją”, znajdowała się wówczas na terenie Ukrainy $^{8}$. Poza tym nie mniej istotne dla ówczesnej, bardzo złej sytuacji Sowietów, a może nawet ważniejsze, były też katastrofalna sytuacja ekonomiczna?

5 Obszerniej vide chociażby: Крестьянское восстание в Тамбовской Губернии в 1919-1921 г2. „Антоновщина”. Документы и материалы, Коллективная работа, Тамбов 1994; Крестьянская революиия в России 1902-1922. Документы и материалы. Под редакцей В. Данилова, Т. Шанина: Том: Крестьянское движение в Поволжве 1919-1922. Документы и материалы. Ответственные редакторы В. Данилов, Т. Шанин, Москва 2002; Крестьянская революиия в России 1902-1922. Документы и материалы. Под редакцей В. Данилова, Т. Шанина: Том: Крестьянское движение в Тамбовской Губернии 1917-1918. Документь и материалы. Ответственный редактор В. Данилов, Москва 2003; В. В. Самошкин, Антоновское восстание, Москва 2005.

${ }^{6}$ Vide choćby: За Советы без коммунистов. Крестьянское восстание в Тюменской губернии 1921. Сборник документов. Составитель В. И. Шишкин, Новосибирск 2000.

7 Szerzej vide chociażby: Ю. А. Поляков, А. И. Чугунов, Конеи Басмачества, Москва 1976; Басмачество. Авторы составители С. А. Шумов, А. Р. Андреев, Москва 2005.

8 Россия ХХ век. Документы. Кронштадт 1921. Составители В. П. Наумов, А. А. Косаковский, Москва 1997; L. Trocki, Moje życie. Próba autobiografii, Warszawa 1930; Г. Г. Алахвердов, Н. Ф, Кузьмин, М. В. Рыбаков, Л. М. Спирин, Н. И. Шатагин, Краткая история гражданской войны в СССР, Москва 1960; Historia Komunistycznej Partii Zwiąku Radzieckiego, praca zbior., Warszawa 1960; Л. Михальчук, Лев Троикий, Минск 1998; W. Rezmer, Możliwość wznowienia wojny polsko-rosyjskiej w 1921 r. Nieznany dokument, „Nad Wisłą i Dnieprem”. Polska i Ukraina w przestrzeni europejskiej - przeszłość i teraźniejszość. Seria: Historia, Systemy Międzynarodowe i Globalny Rozwój, Toruń-Kijów 2003-2004, nr 2-3; A. Nawrocki, Możliwość wznowienia dziatań wojennych z Rosja Radziecka w ocenie polskiego Sztabu Generalnego w okresie rozejmu (jesień 1920 - wiosna 1921), „Rocznik Przemyski”. Historia Wojskowości, 2004, t. XL, z. 1.

9 Warto tutaj zauważyć, że w latach 20. (a także później) bardzo często propaganda sowiecka oraz prominentni działacze bolszewiccy odpowiedzialnością za kłopoty ekonomiczne sowieckiej Rosji próbowali obciążać stronę polską. W jednym ze swoich przemó- 
oraz głód panujący na znacznym obszarze, znajdującym się wtenczas pod władzą bolszewików ${ }^{10}$.

Nie oznaczało to jednakże, że Moskwa zrezygnowała z agresywnych planów i działań podejmowanych przeciw Polsce, a następnie również przeciw sojuszniczej w stosunku do niej Rumunii. W przypadku Rzeczypospolitej, w praktyce, oznaczało to przygotowywanie i inspirowanie różnego rodzaju powstań, akcji dywersyjnych oraz odruchów buntu i sprzeciwu wobec państwa polskiego na jego wschodnich Kresach, choćby ze strony Ukraińców zamieszkujących obszar wchodzących w jego skład Chełmszczyzny, Małopolski Wschodniej i Wołynia. Jednocześnie w celu destabilizacji sytuacji politycznej na tych terenach wykorzystywano także ruch komunistyczny, a nawet próbowano sięgać do antagonizmów, opartych o niedawną wojnę Polski z Zachodnio-Ukraińską Republiką Ludową i jej armią, a mianowicie Ukraińską Armią Halicką. We wczesnych latach dwudziestych jej byłych żołnierzy zamierzano bowiem wykorzystać do akcji dywersyjnych, skierowanych przeciw państwu polskiemu i jego siłom zbrojnym ${ }^{11}$. Podobnie, choć w mniejszym zakresie,

wień w 1922 r. Lew Trocki stwierdził bowiem, że: „[...] największa przeszkoda we wprowadzeniu i sukcesie NEP-u oraz ustabilizowaniu sytuacji wewnętrznej sa powstania organizowane przez Polskę na pograniczu [...]".

${ }^{10}$ Głównym obszarem głodu była wówczas Ukraina - szerzej vide choćby: Голод 1921-1923 років в Україні. Збірник документив і матеріалів. Відповідальній редактор С. В. Кульчийький, Київ 1993; Cz. Rajca, Gtód na Ukrainie, Lublin-Toronto 2005. Ponadto zauważyć należy, że w 1921 i 1922 r. głodem były zagrożone także inne obszary sowieckiej Rosji, jak choćby Powołże. W wyniku rabunkowej i zupełnie nieracjonalnej polityki rolnej bolszewików, następstw wojny domowej w Rosji oraz suszy, która w 1921 r. dotknęła około połowy obszarów, produkujących zboże (21 rolniczych guberni europejskiej oraz azjatyckiej części Rosji), a także innych czynników obiektywnych, w 1922 r. głód objął 26 milionów ludności w Rosji oraz około 7,5 miliona na Ukrainie. W sumie więc dawało to 33,5 miliona głodujących, z czego 7 milionów stanowiły dzieci. Warto też pamiętać, iż według obliczeń niezależnych ekspertów, w razie braku pomocy żywnościowej pochodzącej z zagranicy, z grupy tej około 10-15 milionom ludzi groziła śmierć głodowa lub w najlepszym przypadku trwałe kalectwo, będące następstwem długiego okresu skrajnego niedożywienia - szerzej na ten temat vide choćby: R. Pipes, dz. cyt., s. 440 i passim.

${ }_{11}$ Obszerniej na ten temat zob.: Wrzesien 1939. Radzieckie zagrożenie Rzeczypospolitej $w$ dokumentach, relacjach i wspomnieniach, wybór i oprac. W. Włodarkiewicz, Warszawa 2005; Kresy w oczach oficerów KOP, wstęp i oprac. J. Widacki, Katowice 2005; W. Włodarkiewicz, Radzieckie zagrożenie Rzeczypospolitej w ocenach polskich naczelnych władz wojskowych 1921-1939, Warszawa 2001; tenże, Przed 17 września 1939 roku. Radzieckie zagrożenie Rzeczypospolitej w ocenach polskich naczelnych wtadz wojskowych 1921-1939, Warszawa 2002. 
próbowano również wykorzystać Białorusinów, zamieszkujących Rzeczpospolitą. Jednakże wydaje się, iż w przypadku tej grupy większy wysiłek sowieckie organy wywiadowcze oraz Komintern włożyły w działania mające na celu komunizację tej w większości chłopskiej i jednocześnie mało kulturalnej, a także słabo wykształconej oraz uświadomionej narodowo i politycznie mniejszości ${ }^{12}$.

Władze sowieckie podejmowały takie działania, gdyż psychoza realnego bądź też urojonego zagrożenia zewnętrznego stała się stałym i niezwykle ważnym elementem sowieckiej polityki i propagandy. Przy jej pomocy zarówno w stosunku do własnego społeczeństwa, jak i zagranicy, przez cały okres międzywojenny uzasadniano także konieczność stałej rozbudowy i unowocześniania posiadanych sił wojskowych oraz ich dyslokacji w pobliżu zachodniej granicy sowieckiej Rosji. Działania takie, mimo konieczności przejściowej redukcji stanu liczebnego Armii Czerwonej ${ }^{13}$, podjęto praktycznie niemal natychmiast po zawarciu traktatu ryskiego. W wyniku tego zachodnie obszary sowieckiej Rosji już w latach 20. stały się największym skupiskiem jej sił wojskowych ${ }^{14}$.

Warto także zauważyć, że w latach 30. wraz z rozrostem liczebnym Armii Czerwonej oraz wzrostem jej potencjalnej siły ofensywnej rosła liczba

12 Szerzej, poza częścią wcześniej cytowanej literatury, vide choćby: W. Śleszyński, Walka instytucji państwowych z biatoruska dziatalnościa dywersyjna 1920-1925, Białystok 2005; tenże, Bezpieczeństwo wewnętrzne w polityce państwa polskiego na ziemiach pótnocno-wschodnich II Rzeczypospolitej, Warszawa 2007.

13 Szerzej vide choćby: Rosja sowiecka pod względem spotecznym o gospodarczym, pod red. L. Krzywickiego, t. 1, cz. 2: Polityka w zakresie wymiany i aprowizacji. Polityka robotnicza w Rosji sowieckiej, Toruń-Warszawa 1922; В. Г. Клевцов, Социальные и организационные проблемы военных реборм 20-30-х годов, [w:] Армия и общество. Стати, документы. Ответственный редактор В. П. Дмитренко, Москва 1993; О. Н. Кен, Мобилизационное планирование и политические ретения (конеи, 1920-x - середина 1930-х г2.), Москва 2008. Ponadto vide także część przestarzałej jednak już dzisiaj i mocno zideologizowanej literatury sowieckiej, jak choćby: 50 rem вооружённых сил СССР. Коллегиальная работа, Москва 1968; Р. М. Беджанян, Участие Красной Армии в соииалистическом строительстве (1918-1932), Москва 1969.

${ }_{14}$ Pamiętać należy, że obszar późniejszego Białoruskiego Okręgu Wojskowego aż do 1924 r. w oficjalnej wojskowej i politycznej nomenklaturze sowieckiej nazywany był „Frontem Zachodnim”. Tak więc, pomimo formalnego zakończenia wojny polsko-sowieckiej i wbrew postanowieniom traktatu ryskiego obszar ten nadal traktowany był jako teatr bardzo prawdopodobnych, a przynajmniej potencjalnych w najbliższej przyszłości działań wojennych. 
wielkich jednostek oraz „formacji dyspozycyjnych”15, rozlokowanych na obszarze Białoruskiego i Ukraińskiego ${ }^{16}$ Okręgów Wojskowych. Podobnie było również ze stanami Moskiewskiego ${ }^{17}$ oraz Leningradzkiego Okręgów Wojskowych ${ }^{18}$.

15 Jako „formacje dyspozycyjne” strona polska traktowała wszystkie oddziały Robotniczo-Chłopskiej Armii Czerwonej, jakie nie wchodziły w skład dywizji strzeleckich oraz dywizji kawalerii. Tak więc obok wielkich jednostek i oddziałów, broni pancernej i zmechanizowanych oraz artylerii ciężkiej i przeciwlotniczej pod tym pojęciem kryło się też lotnictwo, formacje chemiczne, saperskie, wartownicze, konwojowe i inne, a także niektóre oddziały i pododdziały piechoty i kawalerii - szerzej vide choćby: Warszawa, Centralne Archiwum Wojskowe (dalej cyt.: CAW), Oddział II Sztabu Głównego I.303.4.3120. Siły zbrojne ZSRR. Tom III. Organizacja, O. de B. i dyslokacja formacji dyspozycyjnych. z. 1 - Opracowanie - Oddziału II Sztabu Głównego 1. dz. 6500/ II.R.T.O., Warszawa 20 IV 1934 r.; tamże, I.303.4.3169. Siły zbrojne ZSRR. Tom III. Organizacja, O. de B. i dyslokacja formacji dyspozycyjnych. Część II. O. de B. i dyslokacja formacji dyspozycyjnych. Zeszyt 1 - Opracowanie - Oddziału II Sztabu Głównego 1. dz. 8800/II.R.T.O, Warszawa 29 II 1936 r.

16 Vide choćby: Краснознаменный Киевский. Очерки истории Краснознаменного Киевского Военного Округа (1919-1988). Издание 3-е, исправленное и дополненное. Коллективная работа под редакцей И. А. Герасимова, В. В. Осипова, В. А. Шарыгина,, Киев 1989. Pamiętać jednak należy, że opracowanie to ma bardziej charakter propagandowy niż historyczny. Stąd też informacje tam zawarte trzeba traktować bardzo krytycznie i w miarę możliwości należy je weryfikować w oparciu o inne źródła. Ponadto zob. także: Р. С. Иринархов, Киевский особый..., Минск 2006.

17 Zob. choćby: Ордена Ленина Московский Военный Округ. Издание 2-е, исправленное и дополненное. Коллективная работа, Москва 1977. Również w przypadku tego opracowania pamiętać należy o tych samych uwagach, jakie zostały podane przy pozycji dotyczącej dziejów Kijowskiego Okręgu Wojskowego. Jest też rzeczą oczywistą, iż w obydwu tych opracowaniach podawane są zupełnie inne, nierzeczywiste, przyczyny wzmacniania sił Armii Czerwonej nad granicą z Polską oraz na pozostałych zachodnich rubieżach ZSRS.

18 Zob.: Warszawa, CAW, Oddział II Sztabu Głównego I.303.4.2955. Meldunek mjr. Sztabu Generalnego Romana Michałowskiego z 8 IV 1928 r.; Warszawa, Archiwum Akt Nowych (dalej cyt. AAN), Instytucje Wojskowe 1918-1939. 296/I/43. Wyciąg z ostatnich wiadomości - Biuro Ewidencyjne „Wschód” Oddziału II Sztabu Generalnego z 7 XI 1921 r.; Warszawa, AAN, Attachés Wojskowi RP 1918-1939. A/II/88. Meldunek Attaché Wojskowego w Rydze Nr 107 z 3 I 1922 r.; Москва, Российский Государственный Военный Архив (dalej суt. РГВА), Штаб РККА. Оперативное Управление. Оперативный Отдел. 7.2.18. Дислокация полевых войск по данным на 1 I 1922 г.; Москва, РГВА, Штаб РККА. Оперативное Управление. Оперативная Часть. 7.2.487. Доклад Главного Командующего Всеми Вооружёнными Силами Республики № 310/Оп. от 20 I 1921 г.; tamże, Выписка из протоко- 
Zupełnie inną postawę polityczną po marcu 1921 r. reprezentowało natomiast państwo polskie, które praktycznie za wszelką cenę, łącznie z uznaniem praw sowieckiej Rosji do panowania nad Ukrainąa ${ }^{19}$, chciało zachować status quo istniejące w tej części Europy w wyniku traktatu ryskiego. Warunkiem sine qua non tego było utrzymanie pokoju i dobrych stosunków ze wszystkimi sąsiadami, a przede wszystkim z obydwoma wielkimi sąsiadami - sowiecką Rosją i Niemcami. W Warszawie zdawano sobie jednak sprawę z rzeczywistego charakteru polsko-sowieckich stosunków politycznych oraz z zagrożenia, jakie dla niepodległości Polski stwarzała Robotniczo-Chłopska Armia Czerwona, szczególnie od końca lat dwudziestych, gdy jej siła poczęła gwałtownie wzrastać. Stąd też praktycznie przez cały okres lat 1921-1939 wzajemne stosunki pomiędzy obydwoma państwami cechowała daleko idąca nieufność, której poziom, obok zmian zachodzących w obydwu krajach, zależał także od wzrostu napięcia, jakie następowało w polityce głównych państw europejskich $^{20}$.

ла заседания Революционного Военного Совета Республики от 19 III 1921 г. за № 132; Warszawa, BN. Archiwum im. Tarasa Szewczenki. Partyzancki Powstańczy Sztab Ukraiński. Mf. Nr 68863. Розвидочний звіт № 8/II - 31 V 1921 p.; tamże, Список повстанческіх відділів на Украіні по стану на 1 VI 1921 p.; tamże, Mf. $\mathrm{Nr}$ 68864. Короткий огляд стратегичноі сітуаціі перед східним кордоном Річі Посполитоі Польськоі на 14 VII 1921 p.; tamże, Короткий огляд війсковоі сітуаціі на терені Украіни на 14 VIII 1921 p.; tamże, Тижневий огляд війсковоі сітуаціі на терені Украіни за період з 28 VIII ро 3 IX 1921 р.; Документы внешней политики СССР. Том четвёртый. 19 марта 1921 2. - 31 декабря 1921 г. Коллективная работа, Москва 1960; Из истории гражданской войны в СССР. Сборник документов и материалов в трех томах 1918-1922. Том третий. Февраль 1920 - октябрь 1922. Коллегиальная работа, Москва 1961. Ponadto zob. także: Rosja sowiecka pod względem spotecznym i gospodarczym, pod red. L. Krzywickiego, Warszawa 1922; Historia Komunistycznej Partii Zwiazku Radzieckiego; R. C. Raack, Polska i Europa w planach Stalina, Warszawa 1997.

19 Stwierdzenia tego nie należy jednak rozumieć w kategoriach jakiegokolwiek podporządkowania polskich interesów któremukolwiek z sąsiadów ówczesnej Rzeczypospolitej ani też jako potencjalną zdolność do kolaboracji z sowiecką Rosją czy też Niemcami, co mogłoby wciągnąć Polskę w jakiś niepożądany konflikt zbrojny - szerzej choćby: M. Kornat, Polityka równowagi 1934-1939. Polska między Wschodem a Zachodem, Kraków 2007.

${ }^{20} \mathrm{Z}$ nowszych wydawnictw źródłowych i opracowań dotyczących tej problematyki, obok części wcześniej cytowanych źródeł i literatury, vide choćby: Agresja sowiecka na Polskę w świetle dokumentów. 17 września 1939. Geneza i skutki, pod red. E. Kozłowskiego, Warszawa 1994; W. Materski, Tarcza Europy. Stosunki polsko-sowieckie 1918-1939, Warszawa 1994; tenże, Na widecie. II Rzeczypospolita wobec Sowietów 1918- 
Nie wolno także zapominać, że w kontekście sytuacji politycznej, w jakiej od 1919 r. znajdowała się Rzeczypospolita, polskie czynniki polityczne w sposób szczególny niepokoił fakt szerokiej i narastającej współpracy wojskowej Armii Czerwonej z niemiecką Reichswehrą, a także współpraca ekonomiczna z Niemcami, dzięki której niemal do połowy lat trzydziestych ZSRS uzyskiwał dostęp do nowoczesnych technologii i myśli technicznej, jakie mógł wykorzystać do budowy oraz rozbudowy własnego i agresywnego potencjału wojskowego. W Warszawie zdawano sobie bowiem sprawę z faktu, że działania te oraz współpraca polityczna ${ }^{21}$ mogły stanowić, i rzeczywiście stanowi$\mathrm{y}^{22}$, śmiertelne zagrożenie dla całości terytorialnej i suwerenności państwowej Rzeczpospolitej Polskiej. Warto też pamiętać, że rok 1939 potwierdził te obawy w całej rozciągłości ${ }^{23}$.

-1943, Warszawa 2005; S. Gregorowicz, M. J. Zacharias, Polska-Zwiazek Sowiecki. Stosunki polityczne 1925-1939, Warszawa 1995; М. П. Гетьманчук, Ризький Мир. Українсько-польскі відносини періоду підготовки, пидписания і ратифікайії Ризького договору 1921 р., Львів 1998; Traktat ryski 1921 roku po 75 latach, pod red. M. Wojciechowskiego, Toruń 1998; М. И. Мельтюхов, Советско-польские войньы. Военно-политическое противоборстве 1918-1939 г2., Москва 2001; Л. Самуэльсон, Красный колосс. Становление военно-промышленного комплекса СССР 1921-1941, Москва 2001; M. Boruta, Wolni z wolnymi, równi z równymi. Polska i Polacy o niepodlegtości wschodnich sąsiadów Rzeczypospolitej, Kraków 2002, a także dzisiaj już nieco przestarzałe prace: J. Kumaniecki, Po traktacie ryskim. Stosunki polsko-radzieckie 1921-1923, Warszawa 1971; M. Leczyk, Polityka II Rzeczypospolitej wobec ZSRR w latach 1925-1934, Warszawa 1976; A. Skrzypek, Kronika koegzystencji. Zarys stosunków polsko-radzieckich w latach 1921-1939, Warszawa 1982; S. Gregorowicz, Polsko-radzieckie stosunki polityczne w latach 1932-1935, Wrocław-Warszawa-Kraków-Gdańsk-Łódź 1982.

${ }^{21}$ Jednym z jej przejawów był choćby podpisany dnia 24 IV 1926 r. w Berlinie traktat o nieagresji zawarty pomiędzy Niemcami a Sowietami.

${ }^{22}$ Dzisiaj bowiem, na podstawie ujawnionych po II wojnie światowej dokumentów dyplomatycznych, głównie niemieckich, wiemy, że już w grudniu 1921 r. Sowiety złożyły Niemcom pierwszą propozycję wspólnej akcji wojskowej przeciw Polsce w celu odebrania jej spornych terytoriów, czyli w praktyce dokonania kolejnego rozbioru. Ofertę tę ponawiały także w 1922 oraz w 1923 r. Niemcy jednak, pomimo swej wrogości w stosunku do Rzeczpospolitej Polskiej, z różnych powodów żadnej z tych propozycji nie rozpatrywały jako możliwego wówczas do zrealizowania planu politycznego lub też wojskowego zob. choćby: K. Grünberg, J. Serczyk, Droga do rozbioru Polski 1918-1939. Nowe ustalenia, Warszawa 2005, s. 86, 88-89, 96.

${ }^{23}$ Warto zauważyć, iż fakty świadczące o szerokiej i narastającej współpracy wojskowej Niemiec i ZSRS strona polska odnotowała już w 1921 i 1922 r. Pierwotnie, zdaniem polskich służb wywiadowczych, była to tylko dostawa materiałów wojennych nie- 
W wyniku takich realiów oba państwa, a mianowicie bolszewicka Rosja i Rzeczpospolita Polska, pomimo formalnego zakończenia działań wojennych,

zbędnych dla Armii Czerwonej, a następnie szkolenie jej kadry dowódczej w Niemczech oraz niemieckie doradztwo wojskowe. Apogeum tej współpracy stanowiły powszechnie już dzisiaj znane poligony doświadczalne, istniejące na terenie ZSRS, na których Niemcy i Sowieci testowali broń pancerną, lotnictwo oraz broń chemiczną. Efekty tej współpracy były pilnie obserwowane przez stronę polską aż do jej wygaśnięcia związanego z przejęciem władzy w Niemczech przez NSDAP. Nie wolno też zapominać o groźnej dla Polski współpracy sowiecko-niemieckiej w okresie wojny polsko-bolszewickiej - szerzej vide choćby: Warszawa, CAW, Oddział II Sztabu Głównego I.303.4.3288. Raport Attaché Wojskowego przy Poselstwie Rzeczpospolitej Polskiej w Berlinie Nr 117/34 z 27 I 1934 r.; tamże, I.303.4.3410. Wojskowa współpraca niemiecko-rosyjska w 1921-1930 roku. Zestawienie chronologiczne - wykonano w Referacie „Niemcy” Oddziału II Sztabu Głównego w lutym 1931 r.; tamże, Niemiecki obóz ćwiczebny dla czołgów „Kama” - Referat „Niemcy” Oddziału II Sztabu Głównego l. dz. 30/N/32.Pol.573 z 25 I 1932 r.; tamże, I.303.4.3463. Sytuacja Niemiec (Raport kwartalny) Attaché wojskowego przy Poselstwie Rzeczpospolitej Polskiej w Berlinie l. dz. 600/33 z 1 VII 1933 r.; Zmowa. IV rozbiór Polski, wstęp i oprac. L. Szcześniak, Warszawa 1990; Sasiedzi wobec wojny 1920 roku. Wybór dokumentów, oprac. J. Cisek, Londyn 1991; Фашистский меч ковался в СССР. Красная Армия и Рейхсвер тайное сотрудничество 1922 -1933. Неизвестные документы. Составители Ю. Л. Дьяков, Т. С. Бушуева, Москва 1992; Рейхсвер и Красная Армия. Документы из военных архивов Германии и России 1925-1931. Составители К. фон Йена, Н. Елисеева, Koblenz 1995; Wojna polsko-sowiecka 1920 roku $w$ dokumentach niemieckiej dyplomacj, oprac. K. Jońca, Wrocław 2002; Вестник Архива Президента Российской Федераиии. СССР - Германия 1933-1941. Коллегиальная работа под редакцей С. Кудряшова, Москва 2009; L. Grosfeld, Polska a stosunki niemiecko-sowieckie 1918-1939, Warszawa 1988; K. Grünberg, J. Serczyk, Czwarty rozbiór Polski. $Z$ dziejów stosunków radziecko-niemieckich w okresie międzywojennym, Warszawa 1990; A. Skrzypek, Nie spetniony sojusz? Stosunki sowiecko-niemieckie 1917-1941, Warszawa 1992; M. Pirko, Z dziejów wspótpracy Armii Czerwonej z Reichswehra w latach 1920-1933, „Wojskowy Przegląd Historyczny", 1992, R. XXXVIII, nr 4 (142); M. Zeidler, Reichswehr und Rote Armee 1920-1939. Wege und Stationen einer ungewöhnlichen Zusamenarbeit, München 1993; J. Wieliczka, Reichswehra i Armia Czerwona. Nawiazanie kontaktów i pierwsze porozumienia 1919-1923, „Zeszyty Naukowe Uniwersytetu Jagiellońskiego”, 1994, z. 112; С. Горлов, Совершенно секретно альянс Москва - Берлин, 1920-1933 г2. (Военно-политические отношения СССР - Германия), Москва 2001; Н. Ćwięk, Przeciw Abwehrze, Warszawa 2001; А. Б. Широкорад, Тевтонский меч и русская брония. Русско-германское военное сотрудничество, Москва 2003; P. Stawecki, Wojsko Marszatka Józefa Pitsudskiego 12 V 1926 - 12 V 1935, Warszawa 2004. Ponadto: I. Jędrzejewska, Wspótpraca Armii Czerwonej i Reichswehry w latach 1917-1933. Wybrane problemy, Toruń 2005. Praca ta jednak wnosi bardzo niewiele do naszej dotychczasowej wiedzy dotyczącej tych kwestii. 
nadal prowadziły przeciw sobie daleko posunięte działania wywiadowcze $e^{24}$ i kontrwywiadowcze ${ }^{25}$, które z jednej strony nakierowane były głównie na ocenę potencjału wojskowego przeciwnika oraz jego możliwości ekonomicznych i sytuacji społecznej, z drugiej zaś na ochronę przed przeciwnikiem informacji dotyczących własnych możliwości wojskowych i ekonomicznych

${ }^{24} \mathrm{O}$ polskim wywiadzie okresu wojny polsko-bolszewickiej oraz o wywiadzie skierowanym przeciwko ZSRS i innym państwom, w latach 1921-1939 graniczącym z Rzeczpospolitą, Polską pisali: A. Pepłoński, Oddziat II Sztabu Generalnego NDWP. Zarys organizacji i dziatalności (1919-1920), „Wojskowy Przegląd Historyczny”, 1994, R. XXXIX, nr 1-2 (147-148); tenże, Wywiad polski na ZSRR 1921-1939, Warszawa 1996; tenże, Wywiad w wojnie polsko-bolszewickiej 1919-1920, Warszawa 1999; A. Misiuk, Stużby specjalne w II Rzeczypospolitej 1918-1939. Powstanie, rozwój organizacyjny, kierunki dziatania, rola w państwie, Warszawa 1994; tenże, Stużby specjalne II Rzeczypospolitej, Warszawa 1998; J. Gzyl, N. Mroczek, Zespoty akt samodzielnych referatów informacyjnych DOK (DOGen.) oraz Samodzielnego Referatu Informacyjnego Dowództwa Floty z lat 1919-1939, „Biuletyn Wojskowej Służby Archiwalnej”, Warszawa 2001, nr 24; tamże, D. Pozniakowska-Hanak, Oddziat II Naczelnego Dowództwa Wojska Polskiego 1919-1921; G. Nowik, Polski radio-wywiad w wojnie z bolszewicka Rosja, "Przegląd Historyczno-Wojskowy”, 2004, R.V (LVI), nr 2 (202); tenże, Operacyjne wykorzystanie radiowywiadu od stycznia do marca 1920 roku, "Przegląd Historyczno-Wojskowy”, 2004, R.V (LVI), nr 4 (204); tenże, Zanim ztamano „ENIGMĘ”. Polski radiowywiad podczas wojny z bolszewicka Rosja 1918-1920. Część 1, Warszawa 2004; tenże, Polski radiowywiad w latach 1918-1920, [w:] Marian Rejewski 1905-1980. Życie ENIGMA pisane, praca zbior., Bydgoszcz 2005; tenże, Zanim ztamano „Enigme” rozszyfrowano Rewolucję. Polski radiowywiad podczas wojny z bolszewicka Rosja 1918-1920, Warszawa 2010; W. Włodarkiewicz, Rola polskiego wywiadu wojskowego w rozpoznaniu zagrożenia sowieckiego Rzeczypospolitej w latach 1932-1939, [w:] Wywiad wojskowy II Rzeczypospolitej, materiały pod red. P. Kołakowskiego, A. Pepłońskiego, Kraków 2011. Warto jednak pamiętać, że nadal nie wszystkie aspekty tej problematyki zostały w należyty sposób przebadane; w dalszym ciągu nasza wiedza w tych kwestiach jest mocno niedostateczna. Z racji ograniczonej objętości materiału tego typu autor nie będzie omawiał natomiast działań podejmowanych w tej kwestii przez stronę sowiecką. O ich istnieniu oraz ewentualnych efektach można się jednak przekonać, dokonując kwerendy w dokumentach Oddziału II Sztabu Generalnego oraz w archiwach rosyjskich - vide choćby: Москва, РГВА, Центр Хранения Историко-Документальных Коллекции (dalej суt. ЦХИДК). Sztab Generalny. Oddział II. 308.3.8. Ocena zestawienia bolszewickiego Biura Wywiadowczego dotyczącego sytuacji wojskowej państw obcych - 1921 r. Ponadto vide także choćby: R. Potocki, Armia Czerwona o Wojsku Polskim w 1932 r., „Wrocławskie Studia Wschodnie", 2001, nr 5.

25 Szerzej zob.: A. Pepłoński, Kontrwywiad II Rzeczypospolitej, Warszawa 2002; A. Krzak, Kontrwywiad wojskowy II Rzeczypospolitej przeciwko radzieckim stużbom specjalnym 1921-1939, Toruń 2007; tenże, Ochrona tajemnicy w Wojsku Polskim w latach 1921-1939, Warszawa, b.r.w. 
oraz bezpieczeństwa swoich służb wywiadowczych. Stąd też ze strony polskiej obiektem tych zainteresowań, podobnie jak w czasie wojny polsko-bolszewickiej, były przede wszystkim sowieckie siły zbrojne, głównie zaś Robotniczo-Chłopska Armia Czerwona oraz przemysł wojenny lub też przemysł mogący pracować na potrzeby sowieckiego wysiłku militarnego. Nie mniejszą wagę przywiązywano również do obserwacji dotyczących życia ekonomicznego, społecznego jak i do zagadnień politycznych oraz do tzw. „akcji prometejskiej”26. Ich skalę oraz zakres i wartość podnosił fakt, iż strona polska ewentualne zagrożenie sowieckie traktowała z najwyższą uwagą i powagą.

Ponadto na podstawie posiadanych wtenczas informacji na temat sowieckiego potencjału wojskowego obydwaj Generalni Inspektorowie Sił Zbrojnych oraz Sztab Główny (Generalny) ${ }^{27}$ przez cały okres międzywojenny prowadzili studia na temat ewentualnego konfliktu polsko-sowieckiego oraz przygotowywali plany działań wojennych - wyłącznie defensywnych. Należy bowiem podkreślić raz jeszcze, że strona polska nie zamierzała prowadzić jakichkolwiek agresywnych operacji zbrojnych przeciw swemu wschodniemu sąsiadowi ${ }^{28}$. Stąd też wszelkie podejmowane przez nią przedsięwzięcia i przygotowania wojskowe, ujęte $\mathrm{w}$ ramy ukończonego $\mathrm{w}$ pierwszych miesiącach 1939 r. „Planu operacyjnego Wschód”, miały całkowicie charakter obronny ${ }^{29}$.

${ }^{26}$ Szerzej vide choćby: S. Mikulicz, Prometeizm w polityce II Rzeczypospolitej, Warszawa 1971.

27 Tam, gdzie to będzie możliwe, autor będzie używał ostatecznej nazwy tej instytucji, jaka w Wojsku Polskim oficjalnie obowiązywała dopiero od 1928 r. Do tego momentu brzmiała ona bowiem: „Sztab Generalny” - vide: Dziennik Rozkazów Wojskowych Nr 36 z 22 XII 1928 r. pozycja 396.

28 Warto tutaj dodać, iż podobny charakter, także w wymiarze strategicznym, miały również polskie fortyfikacje budowane i rozbudowywane w latach 30. na wschodzie - szerzej vide choćby: Z. Pruski - tekst, J. Sadowski - rysunki obiektów fortyfikacyjnych, Bastion Polesie. Polskie fortyfikacje na Polesiu w latach 1920-1939, Przasnysz 2000; Z. J. Cutter, Saperzy polscy 1918-1939. Organizacja, szkolenie i wyposażenie materiatowo-techniczne, Wrocław 2001; tenże, Polskie wojska saperskie w 1939 r. Organizacja, wyposażenie, mobilizacja i dziatania wojenne, Częstochowa 2003. Opracowania te zawierają obszerny wykaz źródeł oraz literatury, dotyczącej tej tematyki. Według założeń naczelnych władz wojskowych, w razie ewentualnego konfliktu Polski i ZSRS, fortyfikacje te miały umożliwić stronie polskiej prowadzenie skutecznych działań obronnych przeciw nacierającej Armii Czerwonej.

29 Szerzej vide choćby: Protokoty z posiedzeń Ścistej Rady Wojennej i Inspektorów Armii za lata 1926-1932. Czesść I, oprac. E. Kozłowski, P. Stawecki, „Studia i Materiały do Historii Wojskowości", t. 24, 1981; Wrzesień 1939. Radzieckie zagrożenie Rzeczypospolitej $w$ dokumentach, relacjach i wspomnieniach; S. Kopański, Wspomnienia wojenne 
Warto też tutaj dodać, iż mniej więcej do początku lat trzydziestych polski wywiad dysponował niezwykle dokładnymi informacjami, dotyczącymi wszystkich wskazanych powyżej zagadnień, głównie zaś organizacji i siły Armii Czerwonej ${ }^{30}$ oraz szeroko rozumianego sowieckiego potencjału ekonomicznego. Także i potem udawało się zbierać sporo ciekawych informacji, stanowiących bardzo cenny materiał statystyczny i porównawczy, pozwalający opracować możliwie pełne i zadowalające odpowiedzi na cały szereg nurtujących stronę polską pytań ${ }^{31}$.

Jednakże zamykanie się Związku Sowieckiego na wpływy zewnętrzne, wzrost represywności całego systemu oraz wiele innych czynników spowodowały, iż od początku lat trzydziestych efektywność polskiego wywiadu systematycznie spadała, co powodowało, iż w powstających wtenczas w Oddziale II Sztabu Głównego opracowaniach pojawiało się coraz więcej znaków zapytania, na które coraz trudniej było znaleźć w marę pewne i zadowalające odpowiedzi. Problemy te dotyczyły jednak przede wszystkim pewnych kwestii szczegółowych, a nie problemów natury zasadniczej.

Warto też zauważyć, że nawet wówczas informacje posiadane przez stronę polską pod wieloma względami były znacznie pełniejsze i dokładniejsze niż

1939-1945, Londyn 1972; Generat Wactaw Stachiewicz. Wierności dochować żotnierskiej. Przygotowania wojenne $w$ Polsce 1935-1939 oraz kampania 1939 r. w relacjach $i$ rozważaniach szefa Sztabu Gtównego i szefa Sztabu Naczelnego Wodza, do druku przygotował M. Tarczyński, Warszawa 1998; Zbiór dokumentów pptk. Edmunda Charaszkiewicza, oprac. i wstęp A. Grzywacz, M. Kwiecień, G. Mazur, Kraków 2000; R. Szubański, Plan operacyjny „Wschód”, Warszawa 1994 (drugie wydanie: Warszawa 2010); W. Baliński, Cztowiek w cieniu. Tadeusz Petczyński. Zarys biografii, Kraków 1994; A. Grzywacz, Armia sowiecka w ocenach polskiego kierownictwa wojskowego 1921-1939, „Studia Rzeszowskie", t. 6, 1999; T. Kośmider, Planowanie wojenne w Polsce w latach 1921-1926, Toruń 2001; W. Włodarkiewicz, Radzieckie zagrożenie Rzeczypospolitej w ocenach polskich naczelnych wtadz wojskowych 1921-1939; tenże, Przed 17 września 1939 roku. Radzieckie zagrożenie Rzeczypospolitej w ocenach polskich naczelnych wtadz wojskowych 1921-1939.

30 Tak samo było również w przypadku sił podległych Ludowemu Komisariatowi Spraw Wewnętrznych, jakimi były chociażby Wojska Pograniczne - szerzej vide choćby: P. Skubisz, Wojska Pograniczne ZSRS na odcinku z Polska w świetle materiatów wywiadu II Rzeczypospolitej (1921-1939). Struktura i dyslokacja. Dziatalność wywiadowcza. Regulamin stużby, Szczecin 2010.

${ }^{31}$ Konrad Paduszek [Kryzys dziatalności polskiego wywiadu wojskowego w Zwiazku Sowieckim (1923-1924. Przyczyny i konsekwencje, „Przegląd Historyczno-Wojskowy”, 2010, R. XI (LXII), nr 2 (231), s. 59-80] twierdzi, że poważny kryzys w działalności polskiego wywiadu wojskowego rozpoczął się już w latach 1923-1924 oraz że trwał on co najmniej do $1927 \mathrm{r}$. 
dane zdobywane wtedy przez wywiady innych sąsiadów ZSRS oraz pozostałych, zainteresowanych tą problematyką państw europejskich, a nawet Japonii ${ }^{32}$. Dowodem na to mogą być chociażby kontakty pomiędzy wywiadami wojskowymi polskim i japońskim, do których dochodziło w latach 1925-1928, gdy funkcję attaché wojskowego w Tokio pełnił najpierw mjr, a następnie ppłk dyplomowany, Wacław Jędrzejewicz. Oficer ten tak po latach wspominał swoje kontakty z japońskim Sztabem Generalnym:

Ustaliliśmy, że będziemy odbywali posiedzenia raz w tygodniu, omawiając na każdym poszczególne zagadnienia. Zaczęło się od porównania wiadomości obu sztabów o dyslokacji wielkich jednostek armii sowieckiej. Przywiozłem ze sobą wielką mapę z oznaczonymi na niej korpusami, dywizjami, brygadami i pułkami wszystkich rodzajów broni według informacji polskich. Japończycy pokazali swoją mapę. Różnice były widoczne. Trzeba było porównać źródła obu sztabów i, jeśli nie uzgodniliśmy dyslokacji danej jednostki, musiałem o tym powiadomić mój w Warszawie, by rozpoczęto poszukiwania faktycznego stanu rzeczy. Podobnie robili Japończycy. Po dłuższym czasie nadchodziły nowe wiadomości, które znowu wspólnie badaliśmy. To samo odnosiło się do innych zagadnień wojskowych, jak Ordre de Bataille wielkich jednostek stanu pokojowego

${ }^{32}$ Vide choćby: Warszawa, CAW, Oddział II Sztabu Głównego I.303.4.3028. Mr Martin - meldunek z 20 II 1931 r.; tamże, I.303.4.3061. O. de B. i dyslokacja wielkich jednostek piechoty i kawalerii RKKA. Stan w dniu 1 XII 1934 r.; tamże, I.303.4.3120. Siły zbrojne ZSRR. Tom III. Organizacja, O. de B. i dyslokacja formacji dyspozycyjnych. Zeszyt 1. - Opracowanie - Oddział II Sztabu Głównego l. dz. 6500/ II.R.T.O., Warszawa 20 IV 1934 r.; tamże, I.303.4.3151. Siły Zbrojne ZSRR. Tom II. Organizacja, O. de B. i dyslokacja wyższych dowództw oraz wielkich jednostek piechoty i kawalerii w czasie pokoju. Część II. O. de B. i dyslokacja wyższych dowództw oraz wielkich jednostek piechoty i kawalerii. Zeszyt 1. - Opracowanie - Oddział II Sztabu Głównego 1. dz. 9250/II.R.T.O., Warszawa 27 X 1935 r.; tamże, I.303.4.3188. Siły zbrojne ZSRR. Organizacja wojenna wielkich jednostek. Zeszyt V. Organizacja wojenna wielkich jednostek lotnictwa - Oddział II Sztabu Głównego l. dz. 11610/II.R.T.O., Warszawa wrzesień 1937 r.; tamże, I.303.4.3214. Siły zbrojne ZSRR. Komunikat wojskowy nr 2 - Oddział II Sztabu Głównego 1. dz. 22026/II.R.T.O., Warszawa kwiecień 1939 r.; tamże, I.303.4.3233. Studium artylerii wojsk obcych za rok 1938. Część II. Zasady działań taktycznych. B. Artyleria sowiecka - Departament Artylerii Ministerstwa Spraw Wojskowych L. 400/Tj.Stud.Og., Warszawa styczeń 1939 r.; tamże, Broń pancerna w wojsku rosyjskim. Opracowano na podstawie materiałów Oddziału II Sztabu Głównego i studiów własnych - Dowództwo Broni Pancernych Ministerstwa Spraw Wojskowych 1. dz. 3243/Tj.Ćwicz.Reg.,39, Warszawa czerwiec 1939 r.; W. Włodarkiewicz, Broń pancerna Armii Czerwonej w 1939 roku. Ocena Dowództwa Broni Pancernych Ministerstwa Spraw Wojskowych Rzeczypospolitej Polskiej, Warszawa 2002. 
i wojennego, zaopatrzenie, mobilizacja, komunikacja (przelotowość linii kolejowych), uzbrojenie, lotnictwo, itd. Te ogólne rozmowy trwały podczas lata, po czym przez cały czas mego pobytu w Tokio uzupełnialiśmy nasze dane. To było właśnie moim zadaniem i zajmowało mi bardzo wiele czasu ${ }^{33}$.

Należy jednak odnotować, iż pomimo wskazanych powyżej i stale narastających trudności w rozpoznaniu sytuacji militarnej Sowietów, nigdy skuteczność polskiego wywiadu wojskowego nie osiągnęła stanu uniemożliwiającego podejmowanie przez polskie czynniki polityczne i wojskowe prawidłowych decyzji, mających zarówno dla Rzeczypospolitej, jak i jej sił zbrojnych znaczenie strategiczne.

Gwoli historycznej rzetelności trzeba jednak zauważyć, że zdecydowane przesunięcie wysiłku wywiadowczego oraz zainteresowań Oddziału II Sztabu Głównego z kierunku sowieckiego na Niemcy, które nastąpiło wiosną 1939 r. ${ }^{34}$, spowodowało, iż wydarzenia związane z tragiczną datą 17 września 1939 r. były dla polskich władz politycznych i wojskowych pewnym zaskoczeniem $^{35}$. Należy jednakże pamiętać o okolicznościach, w jakich nastąpiła sowiecka agresja, oraz o sytuacji politycznej i wojskowej, istniejącej w Europie wiosną i latem 1939 r., a szczególnie o jej gwałtownych zmianach, do których doszło po 23 sierpnia tego roku ${ }^{36}$.

33 W. Jędrzejewicz, Wspomnienia, Wrocław-Warszawa-Kraków 1993, s. 133.

34 Szerzej na ten temat vide choćby: W Kozaczuk, Bitwa o tajemnice. Stużby wywiadowcze Polski i Niemiec 1918-1939, Warszawa 1999; A. Woźny, Niemieckie przygotowania do wojny z Polska w ocenach polskich wtadz wojskowych w latach 1933-1939, Warszawa 2000; H. Ćwięk, Przeciw Abwehrze, Warszawa 2001; R. Majzner, Polski wywiad wojskowy wobec polityki II Rzeszy 1933-1939. Militarne aspekty polityki III Rzeszy w świetle analiz Oddziatu II Sztabu Gtównego Wojska Polskiego, Toruń 2006; J. Białkowski, Aspekty wojskowe polityki zagranicznej Polski w 1939 roku, Toruń 2008; P. Kołakowski, Czas próby. Polski wywiad wojskowy wobec groźby wybuchu wojny w 1939 roku, Warszawa 2012.

35 Dnia 17 września we wczesnych godzinach rannych nadszedt do Sztabu Naczelnego Wodza telefoniczny meldunek dowódcy oddziatu KOP w Czortkowie o przekroczeniu granicy przez oddziaty sowieckie [...]. Wiadomość ta byta zupetnym zaskoczeniem tak dla Naczelnego dowództwa, jak i dla rzadu. Wprawdzie od szeregu dni naptywaty wiadomości o koncentracji wojsk sowieckich nad granica, jednak byto to uważane za naturalne następstwo zblizania się wojny do wschodnich granic Polski. Do ostatniej chwili rzadd nasz otrzymywat uspakajające oświadczenia ze strony sowieckiej - cyt. za: Generat Wactaw Stachiewicz. Wierności dochować żotnierskiej. Przygotowania wojenne w Polsce 1935-1939 oraz kampania 1939, s. 595.

36 Szerzej vide choćby: H. von Herwarth, Między Hitlerem a Stalinem. Wspomnienia dyplomaty i oficera niemieckiego 1931-1945, Warszawa 1992; L. Noël, Agresja nie- 
Zainteresowania polskiego wywiadu sięgały nawet najdalszych zakątków sowieckiego imperium, także tych leżących na dalekiej Syberii. Jest jednak rzeczą oczywistą, że największą uwagę i wysiłek skupiano na terenach leżących w pobliżu granicy Polski z Sowietami, a więc objętych przez Białoruski i Ukraiński Okręgi Wojskowe ${ }^{37}$, a także przez Leningradzki i po części również przez Moskiewski Okręg Wojskowy. Ponadto strona polska pilnie obserwowała także siły Armii Czerwonej, stacjonujące na terenie Północno-Kaukaskiego Okręgu Wojskowego. Najprawdopodobniej zadecydował o tym fakt, iż okręg ten, obok formacji innych broni i służb, stanowił spore skupisko wielkich jednostek sowieckiej kawalerii, a więc broni szybkiej, której przede wszystkim w latach dwudziestych oraz w pierwszej połowie lat trzydziestych, po doświadczeniach wojny polsko-bolszewickiej, strona polska obawiała się w sposób szczególny ${ }^{38}$.

miecka na Polskę, Warszawa 1966; G. Gafencu, Ostatnie dni Europy. Podróż dyplomatyczna w 1939 roku, Warszawa 1984; W. Stachiewicz, Z relacji szefa Sztabu Naczelnego Wodza, [w:] Wrzesień 1939 w relacjach i wspomnieniach, wybór i oprac. M. Cieplewicz, E. Kozłowski, Warszawa 1989; Generat Wactaw Stachiewicz. Wierności dochować zotnierskiej. Przygotowania wojenne w Polsce 1935-1939 oraz kampania 1939; F. Sławoj-Składkowski, Nie ostatnie stowo oskarżonego. Wspomnienia i artykuty, Warszawa 2003; L. Wyszczelski, O czym nie wiedzieli Beck i Rydz-Śmigty, Warszawa 1989; M. Zgórniak, Europa w przededniu wojny. Sytuacja militarna w latach 1938-1939, Kraków 1993; R. Szawłowski („Karol Liszewski”), Wojna polsko-sowiecka 1939, t. 1, Warszawa 1995; Cz. Grzelak, Kresy w czerwieni. Agresja Związu Sowieckiego na Polskę w 1939 roku, Warszawa 1998, a także z pewnymi zasadniczymi zastrzeżeniami: Pamiętniki Józefa Becka (Wybór), wyb. G. Jaszuński, Warszawa 1955.

37 Następnie „specjalnych okręgów wojskowych” - vide choćby: Краснознамённый Киевский. Очерки истории Краснознамённого Киевского Военного Округа (1919-1988).

38 A. Smoliński, Organizacja wielkich jednostek kawalerii Armii Czerwonej oraz ich kadra dowódcza i polityczna w latach 1935 - 1936, [w:] Do szarży marsz, marsz... Studia z dziejów kawalerii, pod red. A. Smolińskiego, Toruń 2012; tenże, Wiedza Oddziału II Sztabu Głównego Wojska Polskiego o stanie organizacyjnym kawalerii i broni szybkich RKKA w połowie lat 30. XX wieku - w druku. Natomiast o wpływie kawalerii Armii Czerwonej na organizację kawalerii Wojska Polskiego szerzej vide choćby: W. Kucharski, Kawaleria i bron pancerna $w$ doktrynach wojennych 1918-1939, Warszawa-Kraków 1984; A. Smoliński, Organizacja kawalerii samodzielnej Rzeczypospolitej Polskiej w latach 1921-1929, „Klio”. Czasopismo poświęcone dziejom Polski i powszechnym, Toruń 2001, nr 1; tenże, Organizacja kawalerii samodzielnej Wojska Polskiego w latach 1930-1939, „Klio”, 2004, nr 5; J. S. Tym, Kawaleria w operacji i w walce. Koncepcje użycia i wyszkolenie kawalerii samodzielnej Wojska Polskiego w latach 1921-1939, Warszawa 
Wydaje się jednak, że spośród tych obszarów zdecydowanie największe zainteresowanie organów polskiego wywiadu wzbudzała Ukraina ${ }^{39}$, traktowana jako ogromny garnizon Armii Czerwonej, spichlerz zbożowy i surowcowy całego Związku Sowieckiego, oraz teren, którego znaczenie gospodarcze ciągle rosło, głównie wobec faktu rozbudowy na tym obszarze przemysłu ciężkiego oraz energetycznego ${ }^{40}$.

Ponadto, przede wszystkim na początku lat dwudziestych, południowo-zachodnia Ukraina była postrzegana przez polskie naczelne władze wojsko-

2006. Zaznaczyć jednak należy, iż nadal jest to problem bardzo słabo znany i niedostatecznie opisany.

39 Szczególne zainteresowanie polskiego wywiadu obszarem Ukrainy datowało się już od 1921 r., a nawet jeszcze wcześniej (vide choćby: T. Nałęcz, Polska Organizacja Wojskowa 1914-1918, Wrocław-Warszawa-Kraków-Gdańsk-Łódź 1984; J. Gul, Dziatalność wywiadowczo-informacyjna obozu niepodlegtościowego w latach 1914-1918, Warszawa 2001). Już bowiem w dniu 8 XI tego roku Oddział II Sztabu Głównego w swojej instrukcji skierowanej do majora Olgierda Górki polskiego Attaché wojskowego w Charkowie stwierdził: Ukraina sowiecka w obecnym uktadzie stosunków interesuje polskie wtadze wojskowe przede wszystkim z punktu widzenia roli jaka odegrać może w ewentualnym konflikcie polsko-bolszewickim (względnie rumuńsko-bolszewickim).... Stąd też Polaków, między innymi, interesowały rzeczywisty stopień „niezależności” Ukrainy sowieckiej od Moskwy; kwestie ewentualnych dążeń separatystycznych mniejszości narodowych na Ukrainie, jak choćby Niemców czy też Tatarów, a także samych Ukraińców oraz sytuacja gospodarcza na Ukrainie. Natomiast ze spraw wojskowych za najistotniejsze uznano: plany mobilizacji przeciw Polsce w ówczesnych Kijowskim i Charkowskim Okręgach Wojskowych, O. de B. i struktura organizacyjna wielkich jednostek Armii Czerwonej, stacjonujących na Ukrainie, oraz obserwacja rozmieszczonych tam formacji kawalerii strategicznej - korpusów, dywizji i samodzielnych brygad - Warszawa, CAW, Oddział II Sztabu Głównego I.303.4.1733. Instrukcja Referatu A. Oddziału II Sztabu Generalnego Wojska Polskiego Nr 9252/II.Inf.II z 8 XI 1921 r. Vide także: R. Torzecki, Kwestia ukrainska w Polsce w latach 1923-1929, Kraków 1989; R. Potocki, Polityka państwa polskiego wobec zagadnienia ukraińskiego w latach 1930-1939, Lublin 2003.

40 Szerzej vide choćby: A. Smoliński, Sytuacja wojskowa, ekonomiczna i spoteczna na sowieckiej Ukrainie w latach 1921-1939 w ocenach Oddziatu II polskiego Sztabu Gtównеgо, „Південний Архів”. Історичні Науки, Міністерство Освіти і Науки України, Херсонський Державний Університет, Херсон, 2004, Випуск 16, s. 239-250; tenże, Sowiecka Ukraina w ocenach Oddziatu II polskiego Sztabu Gtównego Wojska Polskiego - lata 1921-1939, „Nad Wisłą i Dnieprem”. Polska i Ukraina w przestrzeni europejskiej - przeszłość i teraźniejszość. Seria: Historia, Systemy Międzynarodowe i Globalny Rozwój, Toruń-Kijów 2003-2004, nr 2-3, s. 175-196; tenże, Sowiecka Ukraina z lat 1921-1939 w dokumentach Oddziatu II Sztabu Gtównego Wojska Polskiego oraz próba oceny wartości poznawczej tych akt, „Przegląd Wschodni”, (Warszawa) t. 10, 2006, z. 1 (37), s. 107-143. 
we jako dogodny obszar koncentracyjny dla silnego zgrupowania rezerw Armii Czerwonej, mogących stanowić poważne wzmocnienie lewego skrzydła sowieckiego frontu przeciwpolskiego. Nie bez znaczenia był także fakt, że to właśnie z Ukrainy mogło wyjść niezmiernie groźne dla Polski uderzenie, które poza innymi skutkami mogłoby też odciąć Rzeczypospolitą i Wojsko Polskie od sojusznika rumuńskiego oraz od dostaw wojennych, mogących napłynąć głównie przez rumuńskie porty czarnomorskie dla Polski z Zachodu $\mathrm{w}$ razie jej ewentualnego konfliktu z Niemcami ${ }^{41}$.

Największą rolę w polskich działaniach wywiadowczych, skierowanych w okresie międzywojennym przeciw Związkowi Sowieckiemu ${ }^{42}$, odgrywał wywiad wojskowy, a mianowicie Oddział II Sztabu Głównego ${ }^{43}$. Należy jednak pamiętać, że na wschodnich granicach Polski tak zwany „płytki wywiad”, często z bardzo dobrym skutkiem, prowadziły również odpowiednie komórki Korpusu Ochrony Pogranicza ${ }^{44}$. Jednak wszystkie zebrane w ten sposób

41 Szerzej vide choćby: Warszawa, AAN, Attacheés wojskowi RP 1918-1939. A/II/154. Rosja. Referat informacyjny z dnia 15 II 1921 r. - Biuro Ewidencyjne Oddziału II Sztabu Generalnego Naczelnego Dowództwa Wojska Polskiego Nr Ew./5 7478/II; P. Starzeński, Trzy lata z Beckiem, Warszawa 1991; Generat Wactaw Stachiewicz. Wierności dochować żotnierskiej. Przygotowania wojenne w Polsce 1935-1939 oraz kampania 1939... ; Polskie Sity Zbrojne w drugiej wojnie światowej. Tom I. Kampania wrześniowa 1939. Część pierwsza. Polityczne i wojskowe potożenie Polski przed wojna, Londyn 1951; Wojna Obronna Polski 1939, pod red. E. Kozłowskiego, Warszawa 1979; P. Stawecki, Polityka wojskowa Polski 1921-1926, Warszawa 1981; R. Szubański, dz. cyt.; H. Walczak, Sojusz z Rumunią w polskiej polityce zagranicznej w latach 1918-1931, Szczecin 2008.

42 A także, o czym już wspominano, przeciw innym krajom, jak choćby przeciw Niemcom i ich armii oraz Litwie i jej siłom zbrojnym - vide chociażby: T. Gajownik, Tajny front niewypowiedzianej wojny. Dziatalność polskiego wywiadu wojskowego na Litwie w latach 1921-1939, Warszawa 2010.

43 Szerzej na temat dziejów tej instytucji, poza częścią wcześniej cytowanej literatury, vide także: B. Woszczyński, Ministerstwo Spraw Wojskowych 1918-1921. Zarys organizacji i dziatalności, Warszawa 1972; T. Böhm, $Z$ dziejów naczelnych władz wojskowych II Rzeczypospolitej. Organizacja i kompetencje Ministerstwa Spraw Wojskowych w latach 1918-1939, Warszawa 1994; Sztab Generalny (Gtówny) Wojska Polskiego 1918-2003, pod red. T. Paneckiego, F. Puchała, J. Szostaka, Warszawa 2003; P. Olstowski, Oddziat II Sztabu Gtównego Wojska Polskiego - organizacja i funkcjonowanie stużby informacyjno-wywiadowczej II Rzeczypospolitej, [w:] Marian Rejewski 1905-1980. Życie ENIGMA pisane; T. Kmiecik, Sztab Generalny (Gtówny) Wojska Polskiego w latach 1918-1939, Słupsk 2005; L. Wyszczelski, Ministerstwo Spraw Wojskowych (1918-1939), Warszawa 2010.

44 Pamiętać jednak trzeba, że w okresie międzywojennym działania wywiadowcze KOP, oprócz ZSRS, skierowane były również na inne kraje, z jakimi od wschodu grani- 
informacje trafiały do warszawskiej centrali Oddziału II Sztabu Głównego. Tam też podlegały one ostatecznej weryfikacji oraz ocenie i opracowaniu. W wyniku tego powstawały tajne oraz poufne materiały informacyjne, przeznaczone z zasady dla wojskowych oraz politycznych decydentów wysokiego i najwyższego szczebla, a także dla oficerów służących w Generalnym Inspektoracie Sił Zbrojnych oraz w wyższych sztabach i w niektórych placówkach ówczesnego szkolnictwa wojskowego, jak choćby w Wyższej Szkole Wojennej, gdzie, między innymi, służyły one do prac, związanych z szeroko rozumianym planowaniem wojennym, oraz do opracowywania założeń różnego rodzaju gier wojennych, ćwiczeń aplikacyjnych, koncepcyjnych prac sztabowych itd. Jednakże niekiedy niektóre z tych materiałów, w postaci obszernych opracowań, trafiały do nieco szerszego grona ${ }^{45}$. Poza tym część informacji, zdobywanych w latach 1921-1939 przez polski wywiad wojskowy, znajdowała również odzwierciedlenie na łamach ówczesnej prasy wojskowej ${ }^{46}$.

W okresie 1921-1939 bardzo ciekawe i wartościowe wiadomości dotyczące stanu organizacyjnego Armii Czerwonej, w tym także tych jej formacji, które stacjonowały nad granicą z Rzeczpospolitą Polską, oraz ekonomiki i życia „społeczno-politycznego” ówczesnego państwa sowieckiego zbierano, wykorzystując wszelkie możliwe sposoby. Oprócz, co jest rzeczą oczywistą, klasycznego wywiadu agenturalnego, pilnie śledzono również prasę, ukazującą się w sowieckiej Rosji ${ }^{47}$ oraz w krajach z nią graniczących, a także wykorzy-

czyła Rzeczpospolita Polska - szerzej na ten temat vide: Polskie formacje graniczne. Straż graniczna 1918-1939. Dokumenty organizacyjne. Wybór źródet, t. 1, wybór i oprac. B. Polak, Koszalin 1999 (wbrew tytułowi spora część dokumentów dotyczy również KOP); O niepodlegta i granice. Korpus Ochrony Pogranicza 1924-1939. Wybór dokumentów, wybór i oprac. M. Jabłonowski, W. Janowski, B. Polak, J. Prochwicz, Warszawa-Pułtusk 2001; T. Radziwonowicz, Z dziatalności wywiadowczej Korpusu Ochrony Pogranicza, „Zeszyt Naukowy Muzeum Wojska" (Białystok), 1994, nr 8; M. Jabłonowski, J. Prochowicz, Wywiad Korpusu Ochrony Pogranicza 1924-1939, Warszawa 2003/2004; M. Jabłonowski, Formacja specjalna. Korpus Ochrony ogranicza 1924-1939, Warszawa 2002/2003.

${ }^{45}$ Vide choćby: Organizacja sit zbrojnych SSSR w czasie pokoju, oprac. Oddział II Sztabu Generalnego, Wojskowy Instytut Naukowo-Wydawniczy, Warszawa 1924; Wojsko litewskie, oprac. Oddział II Sztabu Generalnego, Wojskowy Instytut Naukowo-Wydawniczy, Warszawa 1925; Mars [Antoni Szymański], Sity zbrojne Niemiec, Wojskowy Instytut Naukowo-Wydawniczy, Warszawa 1931.

${ }^{46}$ Szerzej vide chociażby: J. Romanek, Totalitaryzm sowiecki w ocenie polskiej prasy wojskowej lat 1929-1939, Toruń 2009.

47 Vide choćby: Warszawa, CAW, Oddział II Sztabu Głównego, I.303.4.2979. Raport prasowy nr 10 za czas od 1 XI 1929 r. do 15 I 1930 r.; Warszawa, AAN, Instytucje 
stywano wszelkie informacje uzyskiwane w sposób przygodny od przypadkowych, w większości nieświadomych, informatorów oraz od uciekinierów, którzy z ZSRS, z reguły nielegalnie, przedostawali się na teren Polski ${ }^{48}$. Ponadto cennym źródłem informacji byli także polscy attaché wojskowi ${ }^{49}$ urzędujący najpierw przy Poselstwie Polskim ${ }^{50}$, a następnie przy Ambasadzie Rzeczpospolitej Polskiej w Moskwie ${ }^{51}$, oraz pracownicy cywilni ${ }^{52}$ tej placówki i Konsulatu Generalnego Rzeczpospolitej Polskiej w Kijowie ${ }^{53}$.

Wojskowe 1918-1939, 296/I/82. Informacyjny raport prasowy nr 14/30 za czas od dnia 6 IV do 12 IV 1930 r. - Moskwa 12 IV 1930 r.

${ }^{48}$ Vide choćby: Warszawa, CAW, Oddział II Sztabu Głównego, I.303.4.1852. Załącznik nr 32 do meldunku wywiadowczego nr 6/33 - Ekspozytura nr 5 Oddziału II Sztabu Głównego l. dz. 1805/II.T.O/33, Lwów 30 VI 1933 r.

${ }^{49} \mathrm{O}$ zadaniach oficerów pełniących funkcje attaché przy polskich placówkach dyplomatycznych szerzej vide choćby: Instrukcja ogólna dla attaché wojskowych przy przedstawicielstwach dyplomatycznych Rzeczypospolitej Polskiej, Sztab Generalny Naczelnego Dowództwa Wojska Polskiego, Warszawa 1920. Ponadto vide także: M. Leczyk, Polska i sąsiedzi. Stosunki wojskowe 1921-1939, Białystok 1997; P. Stawecki, Attaché wojskowi Drugiej Rzeczypospolitej, „Przegląd Historyczno-Wojskowy”, 2004, R. V (LVI), nr 2 (202); P. Kołakowski, Instrukcja ogólna dla attaché wojskowych z 10 listopada 1920 r., „Zeszyty Historyczne”, Paryż 2005, z. 151 - szczególnie wstęp do omawianego przez autora dokumentu archiwalnego; R. Majzner, Attachaty wojskowe Drugiej Rzeczypospolitej 1919-1945. Strukturalno-organizacyjne aspekty funkcjonowania, Częstochowa 2011.

${ }^{50} \mathrm{O}$ ich działalności wywiadowczej we wczesnych latach 20. vide choćby: J. Kochanowski, Między dyplomacja a wywiadem. Dziatalność Romualda Wolikowskiego i Ignacego Boernera jako attaché wojskowych w Moskwie (1921-1924), „Przegląd Historyczny”, 1990, nr 1-2; tenże, Zapomniany prezydent... Życie i dziatalność Ignacego Boernera 1875-1933, Warszawa 1993.

${ }^{51}$ Szerzej zob.: A. Smoliński, Raport Aattaché wojskowego przy Ambasadzie $R P$ w Moskwie pptk. dypl. Konstantego Zaborowskiego z podróży po ZSRS odbytej latem 1936 r., [w:] Polska dyplomacja na Wschodzie wXX-poczatkach XXI wieku, pod red. H. Strońskiego, G. Sroczyńskiego, Olsztyn-Charków 2010, s. 344-373; tenże, (А. Смолински), Образ советской деревни летом 1936 г. в докладе военного атташе при Посольстве Республики Польша в Москве подполковника Генерального Штаба Константина Заборовского, [р:] Поляки в истории российской провинции $X I X-X X$ вв. Диалог ичивилизаций. Материалы международной научной конференции 18-20 мая 2010 г, Тамбов 2010, s. 13-36. Ponadto zob.: M. Kruszyński, Ambasada RP w Moskwie 1921-1939, Warszawa 2010.

52 Zob. chociażby: Stanistaw Patek. Raporty i korespondencja z Moskwy (1927-1932), wstęp, wybór i oprac. M. Gmurczyk-Wrońska, Warszawa 2010.

53 W latach 20. na terenie ZSRS Rzeczpospolita Polska posiadała konsulaty w Charkowie (Konsulat Generalny), Kijowie (Konsulat), Mińsku (Konsulat Generalny), Leningradzie (Konsulat) i Tyflisie (Tbilisi - Konsulat Generalny) oraz w Moskwie. Ten ostatni szybko został jednak przekształcony w Wydział Konsularny przy Poselstwie 
Szczególnie cenne i pełne oraz drobiazgowe były informacje oraz raporty przesyłane z Moskwy do Warszawy przez wieloletniego attaché wojskowego w Moskwie i kawalera Krzyża Srebrnego Orderu Wojennego Virtuti Militari oraz dwukrotnego kawalera Krzyża Walecznych, a także innych odznaczeń polskich i obcych, a mianowicie ppłk. Sztabu Generalnego Jana Kowalewskiego, który służbę tę w Moskwie pełnił w latach 1928-1932. Obok wielu bieżących meldunków i informacji wysyłał on także bardzo obszerne sprawozdania roczne, dotyczące całości interesującej nas tutaj problematyki. W każdym z tych dokumentów zawsze znajdowało się wiele wartościowych informacji, dotyczących Armii Czerwonej oraz ówczesnej sowieckiej rzeczywistości politycznej i ekonomicznej. Warto tutaj też dodać, iż cały szereg niezmiernie cennych wiadomości zdobywał on dzięki dobrym stosunkom z attaché wojskowymi innych państw, jacy wraz z nim pełnili wtenczas służbę w Moskwie. Realizację tego zadania ułatwiał mu natomiast fakt niegdysiejszej służby w armii carskiej, gdyż oprócz języka bardzo dobrze znał również realia rosyjskie i był w stanie zrozumieć oraz prawidłowo zinterpretować procesy, jakie zachodziły wówczas w ZSRS. Ponadto był to oficer o dużej kulturze osobistej, który poza wspomnianym już wcześniej językiem rosyjskim znał także francuski, niemiecki, angielski oraz rumuński. Te dwa ostatnie jednak tylko „w mowie”. Umiejętności te w niebagatelny sposób ułatwiały mu natomiast nawiązywanie pożytecznych, z punktu widzenia potrzeb jego służby, kontaktów osobistych ${ }^{54}$.

Polskim w Moskwie. Szerzej na temat tej problematyki vide choćby: Kalendarzyk polityczny na 1930 rok, pod red. S. Cieszkowskiego, Warszawa 1929; T. Joniec, Polska stużba konsularna 1918-1995, Warszawa 1996; W. Skóra, Wspótdziatanie stużby konsularnej II Rzeczypospolitej z wywiadem wojskowym, „Dzieje Najnowsze”. Separatum, Warszawa 2004, R. XXXV, t. 1; tenże, Wspótpraca polskiego wywiadu z placówkami Ministerstwa Spraw Zagranicznych (1921-1923), „Przegląd Historyczno-Wojskowy”, 2005, R.VI (LVII), nr 1 (206); A. Pepłoński, Wywiad a dyplomacja II Rzeczypospolitej, Toruń 2005.

54 Szerzej zob. choćby: Warszawa, CAW, Oddział II Sztabu Głównego, I.303.4.3000. Sprawozdanie Attaché wojskowego przy Poselstwie Polskim w Moskwie za 1932 r.; Warszawa, AAN, Instytucje Wojskowe 1918-1939, 296/I/82. Raport Aattaché Militaire de Pologne a Moscou - 25 XI 1930 r. Ponadto: Warszawa, AAN, 296/I/82. Karta kwalifikacyjna por. Jana Kowalewskiego dla Komisji Kwalifikacyjnej; Rocznik oficerski 1928, Ministerstwo Spraw Wojskowych, Warszawa 1928; P. Stawecki, Oficerowie dyplomowani wojska Drugiej Rzeczypospolitej, Wrocław-Warszawa-Kraków 1997; G. Łukomski, B. Polak, A. Suchcitz, Kawalerowie Virtuti Militari 1792-1945. Wykazy odznaczonych za czyny z lat 1863-1864, 1914-1945, Koszalin 1997. 


\section{Aleksander Smoliński}

Warto także tutaj dodać, że podobnie zbierali dane również oficerowie i pracownicy innych polskich placówek dyplomatycznych, akredytowanych w pozostałych krajach europejskich ${ }^{55}$, jak choćby w Rydze ${ }^{56}$, Tallinie ${ }^{57}$, Helsingforsie (Finlandia) ${ }^{58}$, Ankarze i wielu innych.

Ponadto, szczególnie w latach 20., wymieniano również informacje z organami wywiadu wojskowego sojuszników oraz ich attaché wojskowymi, a także z przedstawicielami innych państw, które, podobnie jak Rzeczpospolita Polska, również posiadały w Związku Sowieckim własne placówki dyplomatyczne. Należały do nich choćby Królestwo Rumunii ${ }^{59}$,

55 Zgodnie z treścią pisma skierowanego przez Oddział II Naczelnego Dowództwa Wojska Polskiego dnia 25 X 1920 r. do Attachattaché wojskowych w Rewlu, Rydze i Helsingforsie oprócz typowych działań wywiadowczych: „[...] ze względu na doniosłe znaczenie wywiadu prasowego dającego możność wewnętrznego obserwowania życia Rosji sowieckiej i panujących tam nastrojów - należy dołożyć wszelkich starań, aby w możliwie najkrótszym czasie zorganizować stałą przesyłkę zdobytych na miejscu gazet sowieckich do Oddziału II ND [czyli Naczelnego Dowództwa Wojska Polskiego przyp. A. S.]" - cyt za: K. Paduszek, Dziatalność propagandowa stużb informacyjno-wywiadowczych Wojska Polskiego w czasie wojny polsko-bolszewickiej 1919-1921. Organizacja, metody, treści, Toruń 2004, s. 90. Warto tutaj także dodać, że szczególnie pożądane były „Izwiestia”, „Prawda”, „Ekonomiczieskaja Żynn” oraz „Kommunisticzieskij Internacionał".

56 Zob. choćby: Warszawa, AAN, Attacheé wojskowi RP 1918-1939, A/II/88. Meldunek Attaché wojskowego w Rydze Nr 418 z 9 III 1922 r.

57 Zob.: Warszawa, AAN, Attachattaché wojskowi RP 1918-1939, A/II/89/2. Meldunek Delegata Naczelnego Dowództwa Wojska Polskiego w Estonii No 225 z 23 III $1921 \mathrm{r}$.

58 Zob.: Warszawa, AAN, Attaché wojkkowi RP 1918-1939, A/II/88. Meldunek Attaché wojskowego Poselstwa Polskiego w Helsingforsie No 1418 z 10 I 1921 r.; tamże, A/II/89. Raport wojskowo-informacyjny fińskiego Sztabu Generalnego za czas od 1 XII do 15 XII 1921 r.; tamże, Raport Attaché wojskowego przy Poselstwie Polskim w Helsingforsie No 1811 z 8 VII 1921 r.; P. Semków, Polsko-finska idea „blokowania Sowietów”. Dziatalność attachatu wojskowego Rzeczypospolitej Polskiej w Finlandii w latach 1927-1931, „Niepodległość”. Czasopismo poświęcone najnowszym dziejom Polski, Warszawa 2003/2004, t. LIII-LIV (XXXIII-XXXIV po wznowieniu).

59 Zob. choćby: Warszawa, CAW, Oddział II Sztabu Głównego I.303.4.2912. Annales a la conference Deuxiemes Bureaux des Etats Majors Generaux Roumain et Polonais a Varsovie - 1926. Ponadto szerzej na temat polsko-rumuńskiej współpracy wojskowej, poza częścią wcześniej cytowanej literatury, zob. także: Materiaty do dziejów sojuszu polsko-rumuńskiego w latach 1921-1931, wstęp i oprac. H. Bułhak, „Studia Historyczne", 1973, nr 3; tenże, Początki sojuszu polsko-rumuńskiego i przebieg rokowań o konwencję wojskowa w latach 1919-1921, „Dzieje Najnowsze”, 1973, nr 3; M. Leczyk, Z dziejów polsko-rumuńskiego sojuszu wojskowego 1926-1932, „Dzieje Najnowsze”, 1994, z. 3; 
Estonia $^{60}$, Łotwa $^{61}$, Finlandia ${ }^{62}$, Turcja, Japonia ${ }^{63}$, USA $^{64}$, Włochy ${ }^{65}$, a także

A. Jaracz, Dziatalność attaché wojskowego Witolda Dzierżykraj-Morawskiego w okresie międzywojennym, „Mars”. Problematyka i Historia Wojskowości. Studia i Materiały, t. 11, Warszawa-Londyn 2001.

${ }^{60} \mathrm{O}$ ówczesnych stosunkach polsko-estońskich szerzej vide: P. Łossowski, Stosunki polsko-estońskie 1918-1939, Gdańsk 1992; R. Pullat, Od Wersalu do Westerplatte. Stosunki estońsko-polskie w okresie międzywojennym, Kraków 2003. Ponadto zob. także: A. Skrzypek, Zwiazek Battycki. Litwa, Eotwa, Estonia i Finlandia w polityce Polski i ZSRR w latach 1919-1925, Warszawa 1972 oraz U. Salo, Polskie sity zbrojne i potencjat militarny $w$ końcu lat trzydziestych $w$ informacjach attaché wojskowego Estonii, [w:] Od armii komputowej do narodowej. II. Dzieje militarne Polski i jej wschodnich sasiadów od XVI do XX wieku...

${ }^{61} \mathrm{~W}$ przypadku wywiadu wojskowego tego państwa jeszcze w drugiej połowie lat 30. regularnie organizowano okresowe konferencje przedstawicieli Oddziału II polskiego i łotewskiego Sztabów Głównych (Generalnych), których celem podstawowym była wymiana informacji, dotyczących Armii Czerwonej oraz sowieckich poczynań wojskowych. Szerzej zob.: Warszawa, CAW, Oddział II Sztabu Głównego, I.303.4.3159. Meldunek Attaché wojskowego przy Poselstwie Rzeczypospolitej w Rydze ppłk. dypl. Andrzeja Liebicha 1. dz. 10/tj.36 z dnia 13 I 1936 r.; tamże, Meldunek Attaché wojskowego przy Poselstwie Rzeczypospolitej Polskiej w Rydze mjr. dypl. Feliksa Brzeskwińskiego l. dz. 307/tjn. 36 z 24 X 1936 r.; Warszawa, AAN, Attaché wojskowi RP 1918-1939, A/II/88. Meldunek Attaché wojskowego w Rydze nr 297 z 18 II 1922 r. O kształcie ówczesnych stosunków polsko-łotewskich szerzej zob.: A. Skrzypek, Zagadnienie polsko-totewskiej konwencji wojskowej 1919-1925, „Z Dziejów Stosunków Polsko-Radzieckich", 1970, t. 6; tenże, Zwiazek Battycki. Litwa, Eotwa, Estonia i Finlandia w polityce Polski i ZSRR; tenże, Stosunki polsko-totewskie 1918-1939, Gdańsk 1997. Pewnych drobnych informacji dostarcza również praca: T. Paluszyński, Walka o niepodlegtość Łotwy 1914-1921, Warszawa 1999.

${ }^{62}$ Zob. choćby: Warszawa, AAN, Attaché wojskowi RP 1918-1939, A/II/89. Raport wojskowo-informacyjny fińskiego Sztabu Generalnego za czas od 1 do 15 XII 1921 r.; tamże, Dyslokacja armii sowieckiej wg danych fińskiego Sztabu Generalnego zebranych do dnia 20 VI 1921 r. Ponadto: A. Skrzypek, Zwiazek Battycki. Litwa, Eotwa, Estonia i Finlandia w polityce Polski i ZSRR....

${ }^{63}$ Poza częścią wcześniej cytowanych źródeł zob. również: Warszawa, CAW, Oddział II Sztabu Głównego, I.303.4.3159. Meldunek Attaché wojskowego przy Ambasadzie Rzeczypospolitej Polskiej w Moskwie ppłk. dypl. Konstantego Zaborowskiego nr 497/tjn. z 10 XI 1936 r.; Historia dyplomacji polskiej, t. 4: 1918-1939, pod red. P. Łossowskiego, Warszawa 1955; E. Pałasz-Rutkowska, A. T. Romer, Historia stosunków polsko-japońskich 1904-1945, Warszawa 1996.

${ }^{64}$ Szerzej na temat ówczesnych polsko-amerykańskich stosunków wojskowych zob.: J. Smoliński, Polsko-amerykańskie stosunki wojskowe 1776-1945, Warszawa 2004.

${ }^{65}$ Informacje uzyskiwane z tego źródła wymagały jednak bardzo wnikliwej i krytycznej oceny oraz całego szeregu działań podejmowanych w celu sprawdzenia i uzupełnienia zawartych w nich wiadomości. Powodowało to, iż niekiedy ich ostateczna ocena 
Francja, choć informacje uzyskiwane z tego ostatniego źródła nie zawsze satysfakcjonowały stronę polską - szczególnie w latach trzydziestych ${ }^{66}$.

Warto również tutaj wspomnieć o licznych zapytaniach i prośbach o informacje, jakie w latach 1936-1937 pod adresem polskiego Oddziału II kierowały organy brytyjskiego wywiadu wojskowego. Dotyczyły one wówczas stanu organizacyjnego i uzbrojenia wielkich jednostek Armii Czerwonej oraz ich wyszkolenia i sowieckich możliwości mobilizacyjnych, a także stanu sowieckiej gospodarki i przemysłu wojennego, komunikacji kolejowej oraz stopnia motoryzacji kraju i jego sił zbrojnych. Jednocześnie Brytyjczyków interesowały również posiadane przez Polskę wiadomości na temat sowieckich doświadczeń i prac nad silnikami rakietowymi, służącymi jako napęd lotniczy, torped itd., oraz dane w kwestii broni biologicznej („bakteriologicznej”) i chemicznej, a także jej ewentualnych testów wykonywanych na ludziach i zwierzętach. W zamian za te informacje strona polska spodziewała się uzyskać przede wszystkim wiedzę o stanie sowieckiego przemysłu wojennego ${ }^{67}$.

brzmiała: [...] bez poważniejszej wartości. Szerzej zob.: Warszawa, CAW, Oddział II Sztabu Głównego, I.303.4.3159. Meldunek Attaché wojskowego przy Ambasadzie Rzeczypospolitej Polskiej w Moskwie ppłk. dypl. Konstantego Zaborowskiego l. dz. 44.tj. z 28 I 1936 r.; tamże, Pismo Samodzielnego Referatu „Rosja” l. dz. 11408/II.Ros. z 23 V 1936 r. $\mathrm{O}$ innych zagadnieniach oraz metodach pracy tej palcówki stosowanych w końcu lat 30. i związanych ze zbieraniem materiałów dotyczących Związku Sowieckiego zob. także: M. Romeyko, Ze wspomnień attaché wojskowego, „Wojskowy Przegląd Historyczny”, 1959, nr 4; tenże, Wspomnienia o Wieniawie i o rzymskich czasach, Warszawa 1990.

${ }^{66}$ Zob. choćby: Warszawa, CAW, Oddział II Sztabu Głównego I.303.4.3142. Russie Sovietique Cavalerie - dokument niedatowany najprawdopodobniej jednak powstały około 1936 r.; Warszawa, AAN, Attaché wojskowi RP 1918-1939, A/II/89/2. Informacje uzyskane w marcu 1921 r. od mjr. Bonne’a francuskiego attaché wojskowego w Rewlu. Kwestia ta jest ważna w kontekście rzeczywistego sposobu funkcjonowania sojuszu polsko-francuskiego oraz interpretacji jego postanowień dotyczących zobowiązań Francji wobec Polski w razie jej potencjalnego konfliktu zbrojnego z Sowietami - szerzej vide choćby: J. Ciałowicz, Polsko-francuski sojusz wojskowy 1921-1939, Warszawa 1970; P. Stawecki, Polityka wojskowa Polski 1921-1926, Warszawa 1981; H. Buthak, Polska-Francja z dziejów sojuszu 1933-1936, Warszawa 2000. Natomiast o specyfice ówczesnych stosunków politycznych francusko-sowieckich oraz o ich potencjalnym wpływie na poziom zainteresowania francuskich służb wywiadowczych siłami zbrojnymi wschodniego sąsiada Rzeczypospolitej szerzej zob. choćby: A. M. Brzeziński, Zagadnienie bezpieczeństwa zbiorowego w Europie w polityce zagranicznej Francji (1919-1939), Łódź 1992; M. Wołos, Francja-ZSRR. Stosunki polityczne w latach 1924-1932, Toruń 2004.

${ }_{67}$ Zob.: Warszawa, CAW, Oddział II Sztabu Głównego, I.303.4.3173. Pytania Anglików dotyczące Armii Czerwonej oraz Wehrmachtu; tamże, Pytania Oddziału II Sztabu Głównego do brytyjskiej Inteligent Service w kwestii Armii Czerwonej. 
Samo wystąpienie przez Intelligent Service do strony polskiej z takim specyficznym katalogiem pytań zdaje się potwierdzać fakt, że Oddział II Sztabu Głównego był wówczas oceniany przez Brytyjczyków jako jedna z dobrze poinformowanych europejskich służb wywiadowczych. Trudno jednak dzisiaj ocenić, na ile informacje uzyskane tą drogą ich zadowalały, choć Polacy zamierzali przekazać im wszystkie posiadane na ten temat dane.

Ponadto, pomimo nie najlepszych stosunków politycznych pomiędzy Polską i Republiką Czechosłowacką w okresie międzywojennym, oraz mimo braku szerszych kontaktów wojskowych ${ }^{68}$, także dzięki okazjonalnej współpracy z wywiadem tego kraju Oddział II Sztabu Głównego zdobywał pewne informacje dotyczące jednak przede wszystkim problematyki niemieckiej ${ }^{69}$.

68 W okresie międzywojennym najszerszy zakres miała współpraca dotycząca zakupu przez Polskę w firmach czeskich broni oraz licencji na jej produkcję. Natomiast na temat tych oraz innych aspektów polsko-czechosłowackich stosunków dyplomatycznych i wojskowych szerzej zob. choćby: Warszawa, CAW, Oddział II Sztabu Głównego, I.303.4.2143. Komunikat informacyjny z dnia 1 XI 1923 r. - Oddział II Sztabu Generalnego Ministerstwa Spraw Wojskowych nr 22105/II.Inf./II.Og., Warszawa 12 XI 1923 r.; Stosunki polsko-czechostowackie 1932-1939 w relacjach dyplomatów II Rzeczypospolitej, oprac. S. M. Nowinowski, Łódź 2006; T. Janowicz, Czesi. Studium historyczno-polityczne, Kraków 1936; A. Szklarska-Lohmannowa, Polsko-czechostowackie stosunki dyplomatyczne w latach 1918-1925, Wrocław 1967; H. Bułhak, Z dziejów stosunków wojskowych polsko-czechostowackich w latach 1921-1927, „Studia do Dziejów ZSRR i Europy Środkowej”, 1969, t. 5; tenże, Z dziejów stosunków wojskowych polsko-czechostowackich w latach 1927-1936, „Studia do Dziejów ZSRR i Europy Środkowej”, 1975, t. 9; P. Stawecki, Polityka wojskowa Polski 1921-1926, Warszawa 1981; J. Gołębiowski, Przemyst zbrojeniowy Drugiej Rzeczypospolitej 1918-1939, Pionki 1993; Z. Dziemianko, Produkcja uzbrojenia artylerii polskiej w latach 1918-1939, „Zeszyty Naukowe Wyższej Szkoły Oficerskiej im. gen. Józefa Bema”, Toruń 2001, R. XXXIV, nr 20; tamże, J. Wiśniewski, Produkcja sprzętu artyleryjskiego w Czechostowacji w latach 1920-1939; tenże, Armia czechostowacka w latach 1932-1938, Toruń 2001; J. Gruchała, Czeskie środowiska polityczne wobec spraw polskich 1920-1938, Katowice 2002; A. Konstankiewicz, Broń strzelecka i sprzęt artyleryjski formacji polskich $i$ Wojska Polskiego w latach 1914-1939, Lublin 2003; M. P. Deszczyński, Ostatni egzamin. Wojsko Polskie wobec kryzysu czechostowackiego 1938-1939, Warszawa 2003.

69 Zob.: Warszawa, CAW, Oddział II Sztabu Głównego I.303.4.3254. Przygotowanie wyszkolonych rezerw dla potrzeb OK. względnie Klein-Krieg - Praga 23 IX 1931 r. - materiały dostarczone przez Czechów na konferencji w styczniu 1931 r.; tamże, Greznschutz - Praha 30 X 1931 r.; tamże, Vlastenecke branne organisace v Hornim Slezsku - zprávy z Brezna 1931 r.; tamże, Zprávy o Grenzschutzu; ibidem, Výcvik a organisacia RW - Brno 19 XI 1931 r.; tamże, I.303.4.3482. Reorganisace RW - materiały z konferencji polsko-czeskiej z lutego 1934 r.; tamże, Materiał doręczony stronie polskiej na konferencji ewidencyjnej polsko-czeskiej w sierpniu 1934 r. 
Część z nich, jak choćby kwestie współpracy wojskowej Niemiec i ZSRS, dostarczały również pewnych danych na temat potencjału wojskowego naszego wschodniego sąsiada ${ }^{70}$.

Nie należy też zapominać o współpracy, jaką głównie na początku lat dwudziestych strona polska prowadziła z wojskowymi organizacjami emigrantów ukraińskich, pozostających wtenczas na terenie Rzeczpospolitej Polskiej ${ }^{71}$.

Natomiast w przypadku Oddziału II Sztabu Generalnego armii litewskiej wskutek bardzo późnego powtórnego nawiązania w miarę normalnych stosunków dyplomatycznych oraz narastającego w końcu lat trzydziestych, zarówno w stosunku do Polski jak i Litwy, zagrożenia niemieckiego wymiana informacji wywiadowczych dotyczących Armii Czerwonej oraz ZSRS nie miała większego znaczenia ${ }^{72}$. Wcześniej, a mianowicie przed 1938 r., stosunki istniejące pomiędzy obydwoma państwami były mocno napięte i nieuregulowane. Jednocześnie zarówno Rzeczpospolita Polska jak i Republika Litewska traktowały się nawzajem jako potencjalni wrogowie, a ich wywiady wojskowe, obok innych zadań, prowadziły działania rozpoznawcze, skierowane

70 Zob.: Warszawa, CAW, Oddział II Sztabu Głównego I.303.4.3410. Niemiecki obóz doświadczalny „Tomka” w Rosji 1928 r. - załącznik do l. dz. 7120/Tjn.

71 Zob. obszerny zespół akt Partyzanckiego Powstańczego Sztabu Ukraińskiego, jaki przechowywany jest obecnie w zbiorach Biblioteki Narodowej w Warszawiе; Г. Сварник, Архівні та рукописні збірки Наукового Товариства ім. Шевченка в Національній Бібліотеці у Варшаві. Каталог-інформатор, Варшава-Львів-Нью-Йорк 2005 oraz: Визвольиі змагання очима контррозвідника (Документальна спадщциа Миколи Чеботаріва), Київ 2003. Ponadto, oprócz części wcześniej cytowanych źródeł i literatury, o problematyce tej wspominał także R. Potocki, Idea restytucji Ukraińskiej Republiki Ludowej (1920-1939), Lublin 1999; tenże, Polityka państwa polskiego wobec zagadnienia ukraińskiego w latach 1930-1939... oraz В. С. Сідак, Т. В. Вронська, Спецслужба держави без території люди, подіi, факти (війскова розвідка та контррозвидка ДЦ в екзилі 1926-1936 рр.), Київ 2003; Т. В. Вроньска, Співпраця уенерівської та польської розвідок у міжвоєнний пеpiod, [w:] VII Ogólnopolskie Forum Historyków Wojskowości. Źródta w badaniach historii wojskowej. Siedlce 17-18 września 2003 r., pod red. K. Pindela, Toruń 2004.

72 Zob. choćby: L. Mitkiewicz, Wspomnienia kowieńskie 1938-1939, Warszawa 1990. Natomiast o pierwszym etapie polsko-litewskich stosunków politycznych, dyplomatycznych i wojskowych, istniejących w latach 1919-1920 szerzej zob.: P. Łossowski, Konflikt polsko-litewski 1918-1920, Warszawa 1996. 
przeciw ewentualnemu przeciwnikowi, czyli bądź to przeciw Wojsku Polskiemu, bądź przeciw armii litewskiej ${ }^{73}$.

Warto też zauważyć, że w latach dwudziestych w kwestiach wojskowych strona polska z reguły dysponowała pełniejszymi i rzetelniejszymi informacjami na temat Robotniczo-Chłopskiej Armii Czerwone, niż wywiady innych wymienionych tutaj państw. Wydaje się więc, iż pomimo wszystkich sygnalizowanych przez badaczy tej problematyki mankamentów oraz ograniczeń i niedociągnięć w pracy Oddziału II Sztabu Głównego, dobrze świadczy to jednak o jakości ówczesnych polskich służb wywiadowczych oraz o prawidłowej analizie i bardzo dobrym opracowywaniu zdobywanych informacji przez odpowiednie komórki w warszawskiej centrali. Dowodem na to mogą być choćby dokładne i stale uaktualniane informacje dotyczące $\mathrm{O}$. de B. oraz dyslokacji, a nawet liczebności i obsady personalnej ${ }^{74}$, wielkich jednostek i oddziałów Armii Czerwonej, jakie polskie organy wywiadowcze sporządzały przez całą dekadę lat dwudziestych ${ }^{75}$. Aby przekonać się o niekiedy

73 Poza częścią wcześniej cytowanych źródeł i literatury vide również: Warszawa, CAW, Oddział II Sztabu Głównego, I.303.4.2035. Komunikat informacyjny nr 3 za czas od 25 VII 1925 r. do 25 X 1925 r. - Dowództwo 6 Brygady Korpusu Ochrony Pogranicza l. dz. 3986/II.tjn.26 z 25 XI 1925 r.; Wojsko litewskie...; Studium planu strategicznego Polski przeciw Niemcom Kutrzeby i Mossora, oprac. P. Stawecki, M. Jabłonowski, Warszawa 1987, s. 60-61; Dokumenty z dziejów polskiej polityki zagranicznej 1918-1939, t. 1: 1918-1932, s. 182-187 - dok nr 37 - Memoriał Szefa Sztabu Generalnego W. Sikorskiego z 19 I 1922 r. zatytułowany „Polityka zagraniczna z punktu widzenia bezpieczeństwa państwa” przyjęty przez Radę Ministrów jako jej uchwała. Ponadto zob.: $\mathrm{Ka}$ zimierz Świtalski. Diariusz 1919-1935, do druku przygotowali A. Garlicki, R. Świętek, Warszawa 1992; Generat Wactaw Stachiewicz. Wierności dochować żotnierskiej; P. Łossowski, Stosunki polsko-litewskie 1918-1929, Warszawa 1966.

74 Zob. choćby: Warszawa, CAW, Oddział II Sztabu Głównego I.303.4.3169. Siły zbrojne ZSRR. Obsada personalna - skorowidz alfabetyczny. Stan na dzień 1 V 1936 r. - Oddział II Sztabu Głównego 1. dz. 9694/II.R.T.O., Warszawa 21 V 1936 r.

75 Zob. choćby: Warszawa, CAW, Oddział II Sztabu Głównego, I.303.4.3028. I Kaвалерийский Полк Красного Козачества - октябрь 1930 г.; tamże, Dane wojskowe o ZSSR. Zeszyt XVI. Dyslokacja pokojowa armii. Część 1. Dyslokacja wielkich jednostek i obozy letnie, Oddział II Sztabu Generalnego L. 5748/II.Inf.Ros.T.O., Warszawa 1 I 1928 r.; tamże, Dane wojskowe o ZSSR. Zeszyt XVI. Dyslokacja pokojowa armii. Część IV. Dyslokacja organów służb. Składy wojskowe, Oddział II Sztabu Generalnego L. 6632/II.Inf.Ros.T.O., Warszawa 3 III 1928 r.; Москва, РГВА (ЦХИДК), Sztab Generalny Oddział II, 308.3.81. Meldunek Placówki 05 L. 44/3 z 8 V 1924 r.; tamże, 308.4.28. Meldunek Oddziału II Sztabu Generalnego z 21 III 1922 r.; tamże, 308.4.41. Pismo Attaché wojskowego przy Poselstwie RP w Tokio L. 27/25 z 30 VI 1925 r.; tamże, Дислокация Красной Армии по данным до 1 VII 1924 г. 
bardzo wysokiej wartości tych danych wywiadowczych, wystarczy porównać je z dokumentami wytworzonymi przez centralne instytucje ówczesnej Armii Czerwonej ${ }^{76}$.

Gorzej pod tym względem, co już sygnalizowano i o czym obszernej w dalszej części tego tekstu, było natomiast w latach trzydziestych, głównie zaś w ich drugiej połowie. Jednak rzetelna ocena poziomu spadku ówczesnej skuteczności działań Oddziału II Sztabu Głównego wymaga dalszych badań źródłowych oraz porównania danych posiadanych wówczas przez stronę polską z odpowiednią dokumentacją sowiecką.

Pilnie śledzono też i odnotowywano wszelkie zmiany organizacyjne związane z modernizacją i rozbudową Armii Czerwonej, a także obserwowano wzrost poziomu jej wyszkolenia, głównie zaś kadry dowódczej. W związku z tym, szczególnie od końca lat dwudziestych, dokładnie obserwowano i analizowano przebieg wszelkiego rodzaju manewrów oraz ćwiczeń wojskowych, uzyskując w ten sposób cały szereg bardzo cennych informacji. W ten sposób strona polska we właściwym czasie zauważyła choćby organizowanie w Armii Czerwonej pierwszych dużych formacji broni pancernej. Jednocześnie już w ocenie manewrów, jakie odbyły się w 1931 r. w poszczególnych sowieckich okręgach wojskowych (w tym także na terenie Ukraińskiego i Białoruskiego oraz Moskiewskiego Okręgów Wojskowych), odnotowano znacznie lepszy niż w poprzednich latach poziom ich przygotowania i przeprowadzenia. Ponadto uwadze polskiego wywiadu nie uszedł fakt, że brały w nich udział znaczne ilości broni pancernych i oddziaty zmotoryzowane, a oddziały broni głównych (piechoty i kawalerii) otrzymały spore ilości środków technicznych.

W konkluzji odpowiedniego meldunku znalazły się natomiast następujące stwierdzenia:

76 Zob. choćby: Москва, РГВА, Штаб РККА. Секретариаты, 7.1.75. Дислокация полевых войск РККА по данным на 10 XII 1921 г.; tamże, 7.1.235. Краткая дислокация стрелковых и кавалерийских войск РККА на 1 I 1923 г.; Москва, РГВА, Штаб РККА. Оперативное Управление. 7.2.18. Справка - перечень дивизий и отдельных бригад РККА по состоянию на 1 IX 1921 г.; Москва, РГВА, Штаб РККА. Организайионное Управление. 7.6.113. Телеграмма Организационного Управления Штаба РККА № 123954 за 21 IX 1921 г.; tamże, Доклад справка Начальника II Отделения Штаба РККА от 5 X 1921 г.; tamże, 7.6.121. Протокол № 1 заседания 2-ой Комисии Сьезда Командующих Округами от 5 II 1922 г. Ponadto zob. także: Protokoty z posiedzeń Ścistej Rady Wojennej i inspektorów armii za lata 1926-1932. Część I... 
Rok 1931 można śmiało określić jako rok motoryzacji i mechanizacji Armii Czerwonej. [...] W ciągu roku 1931 nastąpiło nasycenie, a może nawet do pewnego stopnia i przesycenie oddziałów Armii Czerwonej środkami technicznymi [Warto pamiętać, iż był to dopiero początek gigantycznych zmian w zakresie upancerniania i mechanizowania Armii Czerwonej - przyp. A. S.]. Tej ilości środków technicznych nie odpowiada stopień wyszkolenia dowódców w użyciu tych środków. Prowadzi to często do nieumiejętnego stosowania ich, a bardzo często do bezcelowego szafowania nimi i narażania ich na duże straty. [...]. Natomiast w kwestii wyszkolenia meldunek ten stwierdzał: [...] bezwzględnie należy podkreślić duży postęp. Żołnierz jest wytrzymały, zaprawiony, teoretycznie nieźle wyszkolony, jednak niemal całkowity brak inicjatywy jest przyczyną biernego zachowania się na polu walki i schematycznego wykonywania zadań bojowych. Ten sam brak inicjatywy charakteryzuje dowódców i sztaby. [...] $]^{77}$.

Warto też zauważyć, że w drugiej połowie lat trzydziestych strona polska z dużym i stale rosnącym zainteresowaniem obserwowała rozwój sowieckich formacji powietrzno-desantowych ${ }^{78}$. Wydaje się również, że doświadczenia Armii Czerwonej w tych kwestiach, choćby po części, próbowano przenosić na polski grunt, organizując w Wojsku Polskim pierwsze formacje spadochronowe oraz sport spadochronowy, istniejący przy Lidze Obrony Powietrznej Państwa ${ }^{79}$. Intensyfikacja tych działań nastąpiła zaś, gdy przeprowadzanie podobnych prób i doświadczeń zauważono także po stronie niemieckiej.

77 Warszawa, CAW, I.303.4.3061. Dane wojskowe o ZSSR. Manewry sowieckie w 1931 r. - Oddział II Sztabu Głównego L. 5851/II.tjn.Ros., Warszawa lipiec 1932 r.

78 Warszawa, CAW, I.303.4.3010. Meldunek Attaché wojskowego przy Poselstwie Polskim w Moskwie L. 806/tj. z 14 X 1930 r.; tamże, I.303.4.3230. Manewry sowieckie 1937 r. - Oddział II Sztabu Głównego 1. dz. 21096/II.R.T.O z ? marca 1939 r.; Warszawa, CAW, I.303.4.3061. Dane wojskowe o ZSSR. Manewry sowieckie w 1931 r. - Oddział II Sztabu Głównego L. 5851/II.tjn.Ros., Warszawa lipiec 1932 r.; K. А. Мерецков, На службе народу. Странииь воспоминаний, Москва 1969; А. М. Василевский, Дело всей жизни, Москва 1974. Ponadto zob. także: 50 лет вооружённьх сил CCCP..; Historia sztuki wojennej do roku 1939, pod red. P. A. Rotmistrowa, Warszawa 1967; S. Zaloga, Berety z gwiazdami. Radzieckie wojska powietrznodesantowe, Warszawa 2003; R. Kempa, Piechota powietrzna. Narodziny i organizacja wojsk powietrzno-desantowych 1914-1939, Białystok 2004.

79 Zob. choćby: W. Malinowski, O organizacji oddziatów spadochronowych $w$ Wojsku Polskim przed 1939 r., „Wojskowy Przegląd Historyczny”, 1961, R. VI, nr 2 (19); A. Jońca, Polscy spadochroniarze w II wojnie światowej-barwa i broń. Część 1 - wrzesień 1939, Warszawa 1994, gdzie jednak nie ma żadnych informacji o wykorzystywaniu $\mathrm{w}$ Polsce obcych doświadczeń z formacjami powietrzno-desantowymi. 
Poziom dokładności i szczegółowości informacji, zdobywanych przez polski wywiad wojskowy, uległ znacznemu pogorszeniu dopiero około 1933 roku. Dotyczyło to jednak przede wszystkim nowych, dopiero tworzonych wówczas, formacji Armii Czerwonej. Z drugiej jednak strony należy pamiętać, że w znacznej części były to oddziały i wielkie jednostki broni szybkich, a mianowicie pancerne i zmechanizowane oraz lotnictwo. Nadal jednak bardzo często polski wywiad zdobywał wartościowsze i rzetelniejsze informacje niż wiele wywiadów znacznie silniejszych i bogatszych państw ówczesnej Europy oraz świata. Pewnym, choć nieco pośrednim dowodem, potwierdzającym taką tezę, może być fakt, że z danych wywiadowczych, zgromadzonych przez Oddział II polskiego Sztabu Głównego w 1940 i 1941 r., korzystali także Niemcy, przygotowując się do realizacji planu „Barbarossa”, czyli do napaści na ZSRS ${ }^{80}$.

Jeszcze raz warto też zauważyć, że w przypadku Robotniczo-Chłopskiej Armii Czerwonej zasięg tej penetracji wywiadowczej sięgał niemal każdego nawet najdalszego zakątka sowieckiego imperium, a nie tylko leżących najbliżej granic Polski Ukrainy i Białorusi. Z drugiej jednak strony należy przyznać, iż najintensywniej rozpoznawano jednak garnizony położone w pobliżu granicy z Rzeczpospolitą ${ }^{81}$. Tam praktycznie przez cały okres międzywojenny obserwowano i analizowano praktycznie wszystko - od rozmieszczenia i ruchu wojsk zacząwszy, poprzez zmiany w uzbrojeniu i organizacji zachodzących w Armii Czerwonej, a na poziomie wyżywienia i stanie zdrowotnym oraz higienie „krasnoarmiejców” skończywszy. Podobnie zresztą traktowano również garnizony oraz wojska stacjonujące w pozostałych okręgach wojskowych.

80 Vide choćby: Warszawa, CAW, Oddział II Sztabu Głównego I.303.4.3200. Die Wehrmacht Sowjet-Russlands Kriegsorganisation der grossen Einhaiten (Heft I bis IV). September 1937 - Überzetsung aus dem Polnischen - Kriegsarchiv-Zweigstelle Danzig. Ponadto pewne ślady wykorzystania tych informacji widoczne są także w: F. Halder, Dziennik wojenny. Codzienne zapisy szefa Sztabu Generalnego Wojsk Ladowych 1939-1942, t. 2: Od planów inwazji na Anglię do początków kampanii na Wschodzie (1.7.1940_ -21.6.1941), Warszawa 1973.

81 Ponieważ praktycznie całą sowiecką Ukrainę oraz Białoruś traktowano jako obszar leżący w pobliżu polskiego teatru działań wojennych, to ze szczególnym zainteresowaniem polski wywiad obserwował, między innymi, następujące garnizony, leżące na Ukrainie: Kijów, Berdyczów, Humań, Połtawa, Winnica, Płoskirów, Żytomierz, Szepetówka, Odessa i inne. Natomiast w przypadku Białoruskiego Okręgu Wojskowego największy wysiłek wkładano w obserwację garnizonów w Mińsku, Mohylewie, Bobrujsku, Witebsku, Smoleńsku, Połocku, Wiaźmie, Leplu oraz innych. 
Jednocześnie nie mniejszą wagę przywiązywano też do obserwacji przemysłu wojennego, kwestii rozpoznania ogólnego potencjału gospodarczego, komunikacji, spraw i problemów społecznych oraz politycznych, a także całego szeregu innych nawet z pozoru błahych zagadnień, jakie mogły interesować analityków Oddziału II Sztabu Głównego ${ }^{82}$.

Uwadze polskich wywiadowców nie umknęły również problemy związane z procesem przymusowej kolektywizacji w ZSRS oraz wielkim głodem z początku lat 30., który postrzegano w Polsce jako wielką tragedię ludności ukraińskiej ${ }^{83}$. Jednocześnie poza niewątpliwie ważnymi kwestiami ekonomicznymi oraz społecznymi dostrzegali oni także jego potencjalny oraz rzeczywisty wpływ na wojskowe możliwości Sowietów w drugiej połowie lat trzydziestych $^{84}$.

${ }^{82}$ Zob. choćby: Warszawa, CAW, Oddział II Sztabu Głównego, I.303.4.104. Komunikat informacyjny. Tom IV z dnia 1 II 1925 r. - Oddział II Sztabu Generalnego Ministerstwa Spraw Wojskowych nr 2610/II.Inf.O. z 10 II 1925 r.; tamże, I.303.4.1728. Meldunek informacyjny nr 3 Ekspozytury nr V Oddziału II Sztabu Głównego L. 389/ Tj./28, Lwów 13 V 1928 r.; tamże, I.303.4.1782. Строевая ведомость 7 Самарской имени Английского Пролетариата Кавалерийской Дивизии по состоянию на 1 января 1927 г.; tamże, Строевая ведомость частей 1 Кавалерийской Червоного Козачества Дивизии по состоянию на 1 октября 1927 г.; tamże, Personalia I Korpusu Czerwonego Kozactwa; tamże, I.303.4.1828. Meldunek informacyjny nr 14/31 Ekspozytury nr 5 Oddziału II Sztabu Głównego L. 2255/tj./31, Lwów 15 X 1931 r.; tamże, Meldunek informacyjny nr 17/31 Ekspozytury nr 5 Oddziału II Sztabu Głównego 1. 2130/tj.31, Lwów 12 XI 1931 r.

83 Wiele z wcześniejszych oraz ówczesnych dokumentów wytworzonych przez Oddział II Sztabu Głównego oraz materiałów napływających do niego z innych instytucji zawiera wstrząsające opisy głodu na Ukrainie oraz jego społecznych skutków - zob. choćby: Warszawa, CAW, Oddział II Sztabu Głównego, I.303.4.3003. Raport Konsula Generalnego Rzeczypospolitej Polskiej w Kijowie nr 42/pf./32 z 11 V 1932 r.; tamże, Sprawozdanie z podróży służbowej po Ukrainie odbytej w czasie od 20 do 25 V 1932 r. Obserwowano także późniejsze problemy aprowizacyjne, istniejące na Ukrainie w końcu lat 30. oraz ich wpływ na nastroje społeczne - zob.: Warszawa, CAW, Oddział II Sztabu Głównego, I.303.4.2326. Materiał informacyjny L. 6876/37/M. Referatu „R” Oddziału II Sztabu Głównego z 6 IV 1937 r.; tamże, I.303.4.3003. Raport Konsula Generalnego Rzeczypospolitej Polskiej w Kijowie Nr 3/Sow/16 z 24 IV 1937 r.

${ }^{84}$ Szerzej o tych kwestiach, poza częścią wcześniej cytowanych źródeł i literatury, zob. także: Колективізащія і голод на Україні 1929-1933. Збірник документів і матеріалів. Упорядочники Г. М. Михайличенко, Є. П. Шаталіна, Київ 1992; Упокорення голодом. Збірник документів. Упорядочник М. Мухіна, Київ 1993; Gtód i represje wobec ludności polskiej na Ukrainie 1932-1947. Relacje, pod red. R. Dzwonkowskiego, Lublin 2004; Голодомор 1932-1933 років в Україні. Документи і матеріали. Упорядочник Р. Пиріг, Київ 2007; Polska i Ukraina w latach trzydziestych 
Obfite ślady działalności polskiego wywiadu wojskowego oraz jej efektów pozostały w aktach wytworzonych przez tę instytucję w latach 1921-1939 i które obecnie, przynajmniej po części, stanowią składową narodowego zasobu archiwalnego.

$\mathrm{Z}$ wszystkiego tego, co powyżej napisano, wynika więc, że rola dokumentów z zespołu archiwalnego Oddziału II Sztabu Generalnego w badaniach nad sowieckim zagrożeniem dla Rzeczpospolitej Polskiej w okresie międzywojennym jest trudna do przecenienia. Podobnie jest także w przypadku oceny rzeczywistego sowieckiego potencjału militarnego z tego okresu oraz różnych innych zjawisk o charakterze ekonomicznym, społecznym i politycznym, jakie zachodziły w ówczesnym ZSRS. Stąd też akta te mogą stanowić również poważne i cenne źródło informacji do badań sowietologicznych.

Poza tym dokumenty tego zespołu są niezwykle ważnym źródłem, niezbędnym do badań przynajmniej kilku dziedzin polskiej historii oraz różnorodnych wzajemnych stosunków pomiędzy Polską a Sowietami. Przede wszystkim, co wydaje się oczywistym, są one bardzo istotne w badaniach różnych aspektów historii wojskowej, ale również politycznych dziejów II Rzeczypospolitej z lat 1921-1939 oraz jej stosunków z ówczesnymi sąsiadami. Nie mniej istotna jest też możliwość poznania poprzez ich analizę obcych źródeł inspiracji wielu przedsięwzięć wojskowych o wyłącznie obronnym charakterze, a także szeroko rozumianych militarnych uwarunkowań ważnych decyzji politycznych i ekonomicznych, podejmowanych wówczas przez cywilne władze państwowe. Jednocześnie mają one również ogromne znaczenie dla prawidłowego zrozumienia przyczyn katastrofy, która spotkała Rzeczpospolitą Polską we wrześniu i październiku 1939 roku. Tak więc bez rzetelnego wykorzystania źródeł z omawianego tutaj zespołu archiwalnego, na co starano się wskazać w dotychczasowej części tego studium, nasza wiedza dotycząca tych kwestii będzie mocno niepełna.

- czterdziestych XX wieku. Nieznane dokumenty z archiwów stużb specjalnych, t. 7: Wielki Gtód na Ukrainie 1932-1933, praca zbior., wybór dokumentów i red. nauk. Diana Bojko i in., Warszawa-Kijów 2008; Hotodomor 1932-1933. Wielki Gtód na Ukrainie w dokumentach polskiej dyplomacji i wywiadu, wybór i oprac. J. J. Bruski, Warszawa 2008; Pomór w „raju bolszewickim”. Gtód na Ukrainie w latach 1932-1933 w świetle polskich dokumentów dyplomatycznych i dokumentów wywiadu, oprac. R. Kuśnierz, Toruń 2008; R. Kuśnierz, Ukraina w latach kolektywizacji i Wielkiego Gtodu (1929-1933), Toruń 2005; S. Kulczycki, Hotodomor. Wielki Gtód na Ukrainie w latach 1932-1933 jako ludobójstwo. Problem świadomości, Wrocław 2008. 
Obecnie najwartościowsza część spuścizny aktowej byłego Oddziału II Sztabu Głównego Wojska Polskiego znajduje się w trzech różnych archiwach $^{85}$. Dwa z nich to archiwa znajdujące się obecnie w Polsce - w Warszawie. Znaczna i zdecydowanie najistotniejsza część pozostającego w kraju zasobu aktowego tej instytucji znajduje się w zbiorach Centralnego Archiwum Wojskowego, gdzie przechowywanych jest w sumie 7838 jednostek archiwalnych obejmujących dziesiątki tysięcy stron, w większości maszynopisów, zawierających ogromną ilość bardzo różnorodnych informacji. Są to dokumenty Wydziału Organizacyjnego, mianowicie różnego rodzaju rozkazy, instrukcje, schematy, raporty, opracowania, sprawozdania, komunikaty informacyjne, wytyczne oraz projekty ustaw i rozporządzenia Prezydenta Rzeczypospolitej Polskiej. Poza tym znaleźć tam można również różnorodne akta personalne, spisy i wykazy żołnierzy służących w Oddziale II Sztabu Głównego oraz inne dokumenty związane z jego obsadą personalną, a także karty ewidencyjne i wnioski awansowe. Zachowała się też część dokumentów, należących niegdyś do Centralnej Kartoteki Agentów ${ }^{86}$. Ponadto są tam plany kursów informacyjno-wywiadowczych, służących głównie szkoleniu oficerów wywiadu, wytyczne szkoleniowe, a także preliminarze budżetowe oraz rozliczenia wydatków i sprawozdania finansowe, związane z działalnością wywiadowczą Oddziału II Sztabu Głównego.

Kolejną grupę akt Oddziału II, znajdujących się w tym archiwum, stanowią niezwykle istotne i wartościowe dokumenty Wydziału Wywiadowczego. Są to różnorodne meldunki, raporty i przeglądy prasy obcej oraz depesze, depesze szyfrowe i materiały informacyjne napływające $\mathrm{z}$ wielu placówek wywiadowczych. Poza tym zachowały się także różne rozkazy, zarządzenia

85 Nie wolno też zapominać, że pewna część akt tej instytucji znajduje się również w polskich placówkach kulturalnych za granicą, a mianowicie w Instytucie Józefa Piłsudskiego w Nowym Jorku oraz w Instytucie Polskim i Muzeum imienia Generała Sikorskiego w Londynie - zob. choćby: Instytut Polski i Muzeum Im. Gen. Sikorskiego, Londyn 1970; J. Cisek, Instytut Józefa Pitsudskiego w Ameryce i jego zbiory, Warszawa 1997; J. Zuziak, Polska historiografia wojskowa w Wielkiej Brytanii w latach 1939-1990. Instytucje, ludzie, publikacje, Warszawa 2001. Ponadto niewykluczone, że jakieś należące niegdyś do Oddziału II Sztabu Głównego dokumenty mogą być przechowywane także w innych, niż wymienione w tym tekście, archiwach polskich oraz obcych. Nie wydaje się jednak, aby była to jakaś znacząca część tej spuścizny.

86 Warto tutaj podkreślić, że część spisów agentów lub też tylko potencjalnych współpracowników oficerów polskiego wywiadu wojskowego, działających na kierunku sowieckim, znajduje się obecnie, o czym niżej, w archiwum w Moskwie. 
i instrukcje oraz często bardzo szczegółowe i niezwykle ciekawe komunikaty informacyjne.

Nie mniej istotne są również akta byłego Wydziału Studiów, a więc komórki, gdzie następowała pogłębiona analiza wszystkich zdobywanych informacji oraz ich przetworzenie na dokumenty posiadające odpowiednią wartość informacyjną dla wszystkich instytucji polskich sił zbrojnych, którym potrzebne były wiadomości o potencjalnym przeciwniku. Znaleźć tam można meldunki, mniej lub bardziej obszerne i szczegółowe studia oraz sprawozdania, opracowania i komunikaty, dotyczące bądź to tematyki ogólnej, bądź też poszczególnych komponentów sowieckiego lub też innego potencjału wojskowego, a także wycinki z prasy obcej oraz mapy i szkice.

Wszystkie wyszczególnione powyżej grupy akt uzupełniają dokumenty pozostałe po Wydziale Traktatowym oraz kancelarii Oddziału II Sztabu Głównego. Bowiem również tam znaleźć można biuletyny, regulaminy, różnorodną korespondencję, materiały nadsyłane z attachatów, różne instrukcje oraz dokumenty i pomoce kancelaryjne, jak choćby dzienniki podawcze, czy też kartoteki i spisy imienne oraz indeksy rzeczowe. Poza wszystkim innym na ich podstawie można wnioskować także o charakterze tych dokumentów, które nie zachowały się w zasobie Centralnego Archiwum Wojskowego lub też znajdują się obecnie poza granicami kraju.

Istotną wartość informacyjną, obrazującą jednocześnie efektywność działań polskiego wywiadu wojskowego, posiadają również akta dawnych ekspozytur Oddziału II Sztabu Głównego. Odnaleźć tam można bowiem różnorodne meldunki, raporty, sprawozdania oraz mapy, fotokopie dokumentów i wycinki prasowe wysyłane do centrali, a także zarządzenia i komunikaty otrzymywane z warszawskiej centrali wywiadu.

Wspomniane powyżej dokumenty sporządzane były w wielu językach. Dominuje, co jest oczywistym, język polski. Z języków obcych najczęściej spotykane są natomiast rosyjski oraz niemiecki i francuski. Poza tym część akt spisano po rumuńsku, czesku, angielsku oraz po włosku, grecku i węgiersku, na nawet po hiszpańsku, przy czym również akta tego typu, choćby pośrednio, dotyczą sowieckiego potencjału militarnego, gdyż omawiają rzeczywiste efekty wojskowej pomocy ZSRS, głównie w zakresie sprzętu wojskowego i specjalistów, dla republikańskiej Hiszpanii ${ }^{87}$.

87 Zespół ten dopiero kilka lat temu został opracowany i jest udostępniany polskim oraz obcym historykom. Obecnie obejmuje w sumie około 361 metrów bieżących akt, 
Podkreślić należy, iż mniej więcej około $50 \%$ z tych dokumentów ${ }^{88}$ dotyczy Robotniczo-Chłopskiej Armii Czerwonej oraz różnorodnych aspektów rzeczywistości, istniejącej w Związku Sowieckim przed 17 września 1939 roku. Jednocześnie dominująca część z nich omawia w sposób bezpośredni sytuację wojskową, społeczną, ekonomiczną i polityczną, istniejącą na obszarach leżących w bezpośredniej bliskości granic Rzeczpospolitej Polskiej. Wskutek tego możliwe jest prowadzenie nawet szeroko zakrojonych i dość precyzyjnych badań, dotyczących oceny stanu wiedzy polskiego wywiadu wojskowego oraz polskich naczelnych władz wojskowych na temat rzeczywistego lub choćby jedynie domniemanego stanu potencjału militarnego Sowietów w okresie lat 1921-1939 oraz ich przygotowań do ewentualnej wojny, która miałaby się toczyć na zachodnich rubieżach ZSRS, a więc głównie przeciwko Rzeczpospolitej Polskiej i jej rumuńskiemu sojusznikowi.

Podobny charakter mają także akta przechowywane w zasobie Archiwum Akt Nowych w Warszawie. Dokumenty wytworzone przez Oddział II Sztabu Głównego można bowiem znaleźć w dwóch zespołach, a mianowicie „Attachaty Wojskowe RP 1918-1939” oraz w zespole „Instytucje Wojskowe 1918-1939”. Jest ich tam jednak nieporównanie mniej niż w poprzednio wymienionej instytucji. Wiele z tych materiałów zawiera informacje, których próżno by szukać w Centralnym Archiwum Wojskowym ${ }^{89}$, choć część archiwaliów obu zespołów stanowi dublety dokumentów z CAW.

Kolejna niezwykle ważna oraz jednocześnie obszerna grupa akt tej proweniencji przechowywana jest obecnie w Moskwiew Rosyjskim Państwowym Archiwum Wojskowym (Российский Государственный Военный Архив),

choć niekiedy, szczególnie w starszych publikacjach, spotkać można również inne dotyczącego tej kwestii dane mówiące o 600, a nawet o około 1000 metrów bieżących akt szerzej zob.: Centralne Archiwum Wojskowe. Informator o zasobie, praca zbior., oprac. zaspół A. Bartnik i in., Warszawa 1996, s. 93; Centralne Archiwum Wojskowe im. Bolestawa Waligóry. Informator o zasobie archiwalnym Centralnego Archiwum Wojskowego, pod red. N. Bujniewicz, Warszawa 2008, s. 71; Inwentarz zespołu akt Oddziału II Sztabu Głównego (Generalnego) z lat 1921-1939, Centralne Archiwum Wojskowe, Warszawa 2001 - niepublikowana pomoc archiwalna przeznaczona do użytku wewnętrznego.

${ }^{88}$ Być może nawet, iż problematyka ta stanowi dużo więcej niż 50\% objętości akt tego zespołu.

89 Szerzej na ten temat zob.: W. Janowski, Źródta do dziejów wojskowych Drugiej Rzeczypospolitej w zasobie Archiwum Akt Nowych, [w:] Od armii komputowej do narodowej. II. Dzieje militarne Polski i jej wschodnich sąsiadów od XVI do XX wieku, pod red. M. Krotofila i A. Smolińskiego, Toruń 2005. 
do którego włączono dawne Centrum Przechowywania Historyczno-Dokumentalnych Kolekcji (Центр Хранения Историко-Документальных Коллекции). W chwili obecnej, w dużym zespole („фонде”) „Oddział II Sztabu Generalnego Wojska Polskiego” („2-й Отдел Генерального Штаба Польши [г. Варшава]") znajduje się bowiem aż 3391 jednostek archiwalnych („единиц хранения”) dotyczących lat 1917-1939.

Dalsze dokumenty Oddziału II znajdują się również w zespołach obejmujących akta wytworzone przez poszczególne ekspozytury Oddziału II Sztabu Głównego. Są to następujące zespoły:

a) „Ekspozytura Samodzielnego Referatu Informacyjnego DOK 6 przy Dowództwie 12 Dywizji Piechoty” („Отделение Контрразведки и Особого Информационного Отдела 6-го Военного Округа при Штабе 12 Пехотной Дивизии Польской Армии [г. Тернопол]”) ${ }^{90}$,

b) „Ekspozytura № 1 Oddziału II Sztabu Generalnego Wojska Polskiego [Wilno]” („Экспозитура № 1 2-го Отдела Генерального Штаба Польши [г. Вильно]") ${ }^{91}$,

c) „Ekspozytura № 2 Oddziału II Sztabu Generalnego Wojska Polskiego [Warszawa]” („Экспозитура № 2 2-го Отдела Генерального Штаба Польши [г. Варшава]") $)^{92}$,

d) „Ekspozytura № 5 Oddziału II Sztabu Generalnego Wojska Polskiego [Lwów]” („Экспозитура № 5 2-го Отдела Генерального Штаба Польши [г. Львов]") $)^{93}$,

e) „Ekspozytura № 6 Oddziału II Sztabu Generalnego Wojska Polskiego [Brześć nad Bugiem]” („Экспозитура № 6 2-го Отдела Генерального Штаба Польши [г. Брест-Литовск]") ${ }^{94}$,

f) „Ekspozytura № 3 Oddziału II Sztabu Generalnego Wojska Polskiego [Poznań, Bydgoszcz]” („Экспозитура № 32 -го Отдела Генерального Штаба Польши [г. Познань, г. Быдгощ]") $)^{95}$,

90 Liczącym 496 jednostek archiwalnych z lat 1918-1939.

91 Obejmującym 343 jednostki archiwalne z lat 1920-1939.

92 Obejmującym 644 jednostki archiwalne z lat 1920-1939.

93 Liczącym zaledwie 95 jednostek archiwalnych z lat 1919-1939.

94 Zespół ten zawiera jedynie 57 jednostek archiwalnych z lat 1922-1925.

95 Obejmującym tylko 16 jednostek archiwalnych z lat 1919-1937. 
g) „Ekspozytura № 4 Oddziału II Sztabu Generalnego Wojska Polskiego [Kraków, Katowice]” („Экспозитура № 4 2-го Отдела Генерального Штаба Польши [г. Краков, г. Катовице]”) $)^{96}$,

h) „Ekspozytura w Kowlu Wydziału II Dowództwa Okręgu Generalnego Lublin” („Экспозитура 2-го Отдела Командования Люблинского Генерального Округа [г. Ковель]") ${ }^{97}$. W sumie akta te stanowią bardzo pokaźny zespół badawczy obejmujący aż 5070 jednostek archiwalnych $^{98}$.

Dokumenty te zapewne nigdy już nie powrócą do Polski, mimo iż ich wartość z punktu widzenia potrzeb polskiej historiografii jest trudna do przecenienia ${ }^{99}$. Jest tam bowiem cały szereg akt, jakich nie ma w Polsce, a dotyczących choćby organizacji i zasad działania polskiego wywiadu z lat 1921$-1939^{100}$, a także jego rzeczywistych efektów zarówno w odniesieniu do ZSRS i Armii Czerwonej, jak i sił zbrojnych oraz ekonomiki innych sąsiadów Rzeczpospolitej Polskiej oraz pozostałych armii Europy, a nawet świata. Dodać tutaj jednak należy, że najważniejsza ich część dotyczy działań wywiadowczych, skierowanych przeciw Związkowi Sowieckiemu i jego siłom zbrojnym.

Na podstawie tego, co powyżej napisano, można stwierdzić, że bardzo obszerna dokumentacja archiwalna, jaka do dnia dzisiejszego pozostała po róż-

96 Zespół ten zawiera jedynie 17 jednostek archiwalnych z lat 1920-1936.

97 Obejmującym tylko 11 jednostek archiwalnych z lat 1921-1935.

98 Szerzej zob. także: Указатель фондов инностранного происхождения и Главного Управления по Делам Военнопленных и Интернированных НКВДМВД СССР Российского Государственного Военного Архива. Коллегиальная работа под редакцей В. П. Козлова и В. Н. Кузеленкова, Федеральная Архивная Служба России Российский Государственный Военный Архив, Москва 2001, s. 22-29. Ponadto zob. także: K. Paduszek, Dokumenty Oddziatu II Sztabu Generalnego w Rosyjskim Państwowym Archiwum Wojskowym, „Przegląd Historyczno-Wojskowy”, 2011, R. XII (LXIII), nr 3 (236), s. 207-214.

99 Zob. B. Woszczyński, Materiaty przekazane Centralnemu Archiwum Wojskowemu ze Związku Radzieckiego, „Wojskowy Przegląd Historyczny”, 1964, R. IX, nr 4 (33); J. Ciesielski, Losy polskich archiwaliów wojskowych po 1 września 1939 r., "Wojskowy Przegląd Historyczny", 1992, R. XXXVII, nr 1 (139).

100 Pamiętać także należy, że w wielu wypadkach dokumentacja ta dotyczy nawet działalności poprzedników Oddziału II Sztabu, najpierw Generalnego, a potem Głównego Wojska Polskiego. 
nych komórkach Oddziału II Sztabu (Generalnego) Głównego, może stanowić niezwykle ciekawy oraz wartościowy materiał badawczy, umożliwiający znaczne pogłębienie naszej współczesnej znajomości poziomu polskiego stanu wiedzy na tematy dotyczące sowieckiej Rosji oraz Związku Sowieckiego z lat 1921-1939101. Z badawczego punktu widzenia ważny jest także ten fakt, że dokumenty te nie dotyczą wyłącznie kwestii wojskowych, choć te zdecydowanie dominują, a opisują praktycznie wszystkie aspekty życia politycznego, społecznego i ekonomicznego tego kraju. Jednocześnie widać w nich również stopniowe i bardzo intensywne narastanie potęgi ekonomicznej oraz militarnej naszego ówczesnego wschodniego sąsiada.

Jeszcze raz należy więc podkreślić, iż poznanie wszystkich tych kwestii oraz sposobu ich widzenia i oceny przez polskie czynniki polityczne i wojskowe okresu międzywojennego pozwoli lepiej zrozumieć cały szereg naszych ówczesnych posunięć politycznych i wojskowych, a nawet gospodarczych i kulturalnych, jakie miały miejsce w dwustronnych stosunkach Rzeczpospolitej Polskiej i ZSRS. Wiedza ta pozwoliłaby też pozbyć się w końcu wielu dotyczących ich stereotypów oraz dość wątpliwej wartości opinii i poglądów, jakie niekiedy nadal pokutują w polskiej, i nie tylko, historiografii.

Tymczasem wydaje się, iż współczesnych badaczy, zajmujących się historią polskiego wywiadu oraz dziejami wojskowymi Polski okresu międzywojennego, interesują głównie kwestie związane z problematyką ściśle wojskową oraz metodami i funkcjonowaniem rodzimych oraz obcych służb wywiadowczych. Warto więc pamiętać, iż zarówno ze względu na wielkość tego zespołu archiwalnego oraz z powodu jego bardzo wysokiej wartości źródłowej, zakres potencjalnej tematyki badawczej może, i powinien, być znacznie szerszy i, jak to już podkreślano, poza omawianą tutaj szeroko pojmowaną problematyką sowietologiczną winien także dotyczyć stosunków wojskowych i politycznych II Rzeczypospolitej z wieloma jej ówczesnymi sąsiadami oraz innymi państwami europejskimi ${ }^{102}$.

101 Pamiętać też należy, że jest tam również dokumentacja wcześniejsza, a więc z okresu z okresu wojny polsko-bolszewickiej.

102 O potencjale i wartości źródłowej akt z tego zespołu archiwalnego mogą świadczyć chociażby następujące wcześniejsze, oparte pogłębioną kwerendę w znajdujących się tam dokumentach, publikacje autora tego studium - zob.: A. Smoliński, Sytuacja wojskowa, ekonomiczna i spoteczna na sowieckiej Ukrainie w latach 1921-1939 w ocenach Oddziatu II polskiego Sztabu Gtównego, s. 239-250; tenże, Sowiecka Ukraina w ocenach Oddziatu II Sztabu Gtównego Wojska Polskiego - lata 1921-1939, s. 175-196; Robotniczo- 


\section{Aleksander S molinski}

An attempt to assess information value of the Division II of the General Staff of the Polish Armed Forces Archives in the context of possible description of military, economic and social situation of USSR in 1921-1939

\section{Su m m a r y}

Virtually throughout the whole period of 1921-1939 the political relations between Poland and USSR could be characterized by far-reaching distrust. This meant that both countries led against each other a large-scale intelligence. Polish armed forces military intelligence was mainly led by Division II of the General Staff of the Polish Armed Forces. Its aim was to identify and assess, as understood in wider context, Soviet military capabilities, especially the Workers and Peasants Red Army forces, as well as the Soviet communication system and capabilities of the military industry and industry which could have potential of supporting military efforts of the state and its armed forces. No less important task of the officers and employees of the Division II of the General Staff was to protect its own military capability against the Soviet military intelligence penetration. Author of this article undertook the analysis of the quantity, content and information value of the remaining archives of the Division II presently spread across several state archives in Poland, as well as archives abroad. These documents are crucial in understanding the extent and impact

-Chtopska Armia Czerwona oraz sowiecki przemyst wojenny z lat 1921-1939 w dokumentach Oddziatu II Sztabu Gtównego Wojska Polskiego, [w:] Polski wywiad wojskowy 1918-1945, pod red. P. Kołakowskiego, A. Pepłońskiego, Toruń 2006, s. 281-331; tenże, Oddziat II Sztabu Gtównego Naczelnego Dowództwa Wojska Polskiego, „Wschodni Rocznik Humanistyczny”, (Lublin - Radzyń Podlaski - Siedlce) 2006, t. 3, s. 269-288; tenże, Sowiecka Ukraina z lat 1921-1939 w dokumentach Oddziatu II Sztabu Gtównego Wojska Polskiego oraz próba oceny wartości poznawczej tych akt, s. 107-143; tenże, Komunikat informacyjny Oddziatu II Sztabu Gtównego z dnia 15 października 1933 roku, „Wschodni Rocznik Humanistyczny”, (Lublin - Radzyń Podlaski - Siedlce) 2008, t. 5, s. 287-315; tenże, Raport Attaché wojskowego przy Ambasadzie RP w Moskwie pptk. dypl. Konstantego Zaborowskiego z podróży po ZSRS odbytej latem 1936 r., [w:] Polska dyplomacja na Wschodzie w XX-początkach XXI wieku, pod red. H. Strońskiego, G. Sroczyńskiego, Olsztyn-Charków 2010, s. 344-373; tenże, (А. Смолински), Образ Красной Армии и СССР в 1921-1939 г2. в документах II Отдела Генерального Штаба Войска Польского, „Клио”, (Санкт-Петербург) 2010, № 3 (50), s. 122-131; tenże, (А. Смолински), Образ советской деревни летом 1936 г. в докладе военного атташе при Посольстве Республики Польша в Москве подполковника Генерального Штаба Константина Заборовского, [w:] Поляки в истории российской провиници $X I X-X X$ вв. Диалог ицивилизаций. Материалы международной научной конференции 18-20 мая 2010 г, Тамбов 2010, s. 13-36. 


\section{Aleksander Smoliński}

of its intelligence activities in years 1921-1939 targeting the USSR. Author's deliberations and conclusions were mainly formulated based on the most significant, most comprehensive and most valuable archival units of that collection currently held in Poland in the Central Military Archives and the New Records Archives, as well as archives of this creator which are part of archival collections in the Russian State Military Archive (Российский Государственный Военный Архив) in Moscow, which also incorporated the former Storage Centre, Historical-Documentary Collection (Центр Хранения Историко-Документальных Коллекции). Author's painstaking study shows, that it is difficult to overestimate the value of Division II archives when conducting research on Soviet threat to Poland in the interwar period. Similar, it is also difficult to assess the Soviet military capabilities at this time, and other various phenomena of economic, social and political nature, which occurred in the former USSR. Therefore, this archival collection may be a significant and valuable source of information for Soviet research. To this day we have preserved many records from different units of the Division II that may be considered very interesting and valuable research material. This material could considerably enhance our understanding of the level of knowledge of the Polish state on matters regarding Soviet Union in the years 1921-1939. From a research point of view, it is important that these documents do not relate exclusively to the military matters, even though dominant, but they provide description of all aspects of political, social and economic life of the country. 